Prepared in cooperation with the Michigan Department of Environmental Quality

\title{
Antibiotic, Pharmaceutical, and Wastewater-Compound Data for Michigan, 1998-2005
}

Scientific Investigations Report 2009-5217 



\section{Antibiotic, Pharmaceutical, and Wastewater-Compound Data for Michigan, 1998-2005}

By Sheridan Kidd Haack

Prepared in cooperation with the Michigan Department of Environmental Quality

Scientific Investigations Report 2009-5217 


\title{
U.S. Department of the Interior \\ KEN SALAZAR, Secretary \\ U.S. Geological Survey \\ Marcia K. McNutt, Director
}

\section{U.S. Geological Survey, Reston, Virginia: 2009}

\author{
For more information on the USGS — the Federal source for science about the Earth, its natural and living resources, \\ natural hazards, and the environment, visit http://www.usgs.gov or call 1-888-ASK-USGS \\ For an overview of USGS information products, including maps, imagery, and publications, \\ visit http://www.usgs.gov/pubprod \\ To order this and other USGS information products, visit http://store.usgs.gov
}

\begin{abstract}
Any use of trade, product, or firm names is for descriptive purposes only and does not imply endorsement by the U.S. Government.

Although this report is in the public domain, permission must be secured from the individual copyright owners to reproduce any copyrighted materials contained within this report.
\end{abstract}

Suggested citation:

Haack, S.K., 2009, Antibiotic, pharmaceutical, and wastewater-compound data for Michigan, 1998-2005:

U.S. Geological Survey Scientific Investigations Report 2009-5217, 36 p. 


\section{Contents}

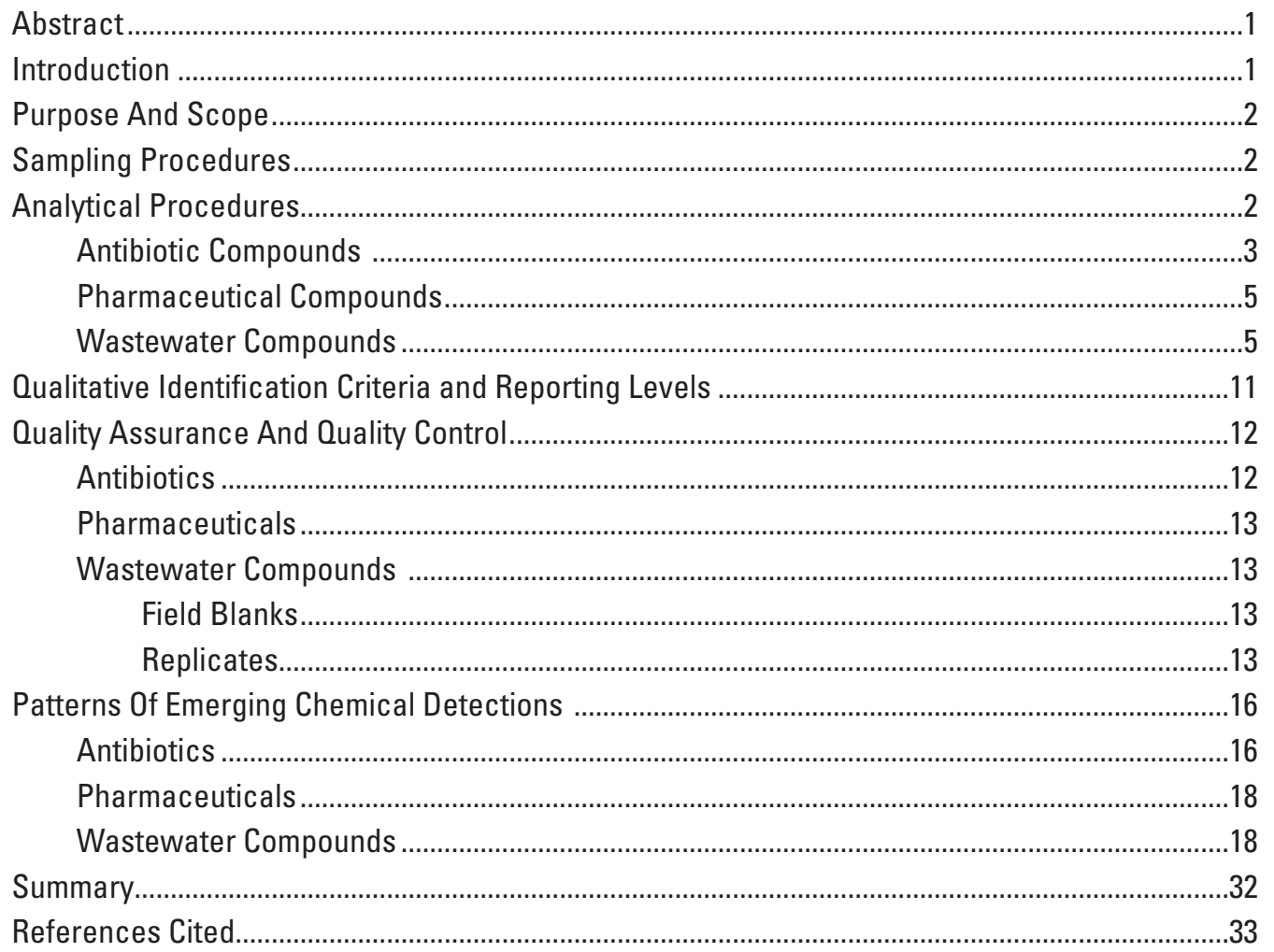

(Appendix A. Antibiotic, Pharmaceutical, and Wastewater Compounds Detected in Michigan Waters is available as a separate downloadable Excel file through a link on the HTML index page at http://pubs.usgs.gov/sir/2009/5217/

A-1. Data for antibiotic compounds in filtered water

A-2. Data for pharmaceutical compounds in filtered water

A-3. Data for wastewater compounds in unfiltered water

A-4. Data for wastewater compounds in filtered water

\section{Figures}

1. Map showing locations of sampling sites.

2-5. Graphs showing:

2. Relation between concentrations of caffeine determined by two different methods.

3. Concentrations of veterinary and general use antibiotics at sites where antibiotics were detected.

4. Number of detections of wastewater compounds, by chemical category, in the River Raisin above and below the city of Adrian, Michigan

5. Number of detections of wastewater compounds, by chemical category, in two reaches of the Galien River during low- and high-flow conditions. 


\section{6-7. Maps showing:}

6. The Pigeon River and Pinnebog River watersheds in Huron County, showing the number of detections of wastewater compounds in four chemical categories, by sampling site.

7. Five watersheds in Oakland County, showing the number of detections of wastewater compounds in four chemical categories, by sampling site.

\section{Tables}

1. Names of antibiotic compounds and their current (2009) reporting levels

2. Names of pharmaceutical compounds, their uses, and their current (2009) and 1999 reporting levels.

3. Names of wastewater-method compounds and their possible uses or sources

4. Names of wastewater-method compounds and their reporting-level variations among filtered and unfiltered analyses, over time.

5. Compounds detected in field and equipment blanks.

6. Concentration of caffeine in samples analyzed by the pesticide-analysis method and by the wastewater-analysis method.

7. Wastewater compounds detected in unfiltered water samples in order of detection frequency.

8. Wastewater compounds detected in filtered water samples in order of detection frequency.

9. Wastewater compounds detected in filtered water, in Michigan, grouped by chemical use or typical source.

10. Detections of wastewater compounds in unfiltered water by sampling site, sampling date, and chemical category

11. Detections of wastewater compounds in filtered water by sampling site, sampling date, and chemical category. 


\section{Conversion Factors and Abbreviated Water-Quality Units}

\begin{tabular}{lcl}
\hline \multicolumn{1}{c}{ Multiply } & \multicolumn{1}{c}{ By } & \multicolumn{1}{c}{ To obtain } \\
\hline inch (in.) & \multicolumn{1}{c}{ Length } \\
foot (ft) & 2.54 & centimeter $(\mathrm{cm})$ \\
mile $(\mathrm{mi})$ & 0.3048 & meter $(\mathrm{m})$ \\
milliliter $(\mathrm{mL})$ & 1.609 & kilometer $(\mathrm{km})$ \\
microliter $(\mu \mathrm{L})$ & 0.03381 & ounce, fluid $(\mathrm{fl} . \mathrm{oz})$ \\
micrometer $(\mu \mathrm{m})$ & 1000 & milliliter $(\mathrm{mL})$ \\
\hline
\end{tabular}

Concentrations of chemical constituents in water are given either in micrograms per liter ( $\mu \mathrm{g} / \mathrm{L})$.

\section{Abbreviations}

$\begin{array}{ll}\text { AHTN } & \text { acetyl hexamethyl tetrahydronaphthalene } \\ \text { APOWCs } & \text { antibiotics, pharmaceuticals, and organic-wastewater compounds } \\ \text { CLLE } & \text { continuous liquid-liquid extraction } \\ \text { DEET } & \text { N,N-diethyltoluamide } \\ \text { GC/MS } & \text { gas chromatography/mass spectrometry } \\ \text { HDPE } & \text { high-density polyethylene } \\ \text { HHCB } & \text { hexahydrohexamethylcyclopentabenzopyran } \\ \text { HPLC/MS } & \text { high-performance liquid chromatography/mass spectrometry } \\ \text { LC/MS-ESI(+) } & \text { liquid chromatography/mass spectrometry positive-ion electrospray } \\ & \text { analysis } \\ \text { LRL } & \text { laboratory reporting level } \\ \text { LT-MDL } & \text { long-term method detection limit } \\ \text { MDL } & \text { method detection limit } \\ \text { MRL } & \text { minimum reporting level } \\ \text { NFM } & \text { National Field Manual } \\ \text { NWOL } & \text { National Water Quality Laboratory } \\ \text { R } & \text { coefficient of determination } \\ \text { SIM } & \text { selected ion monitoring } \\ \text { SPE } & \text { solid-phase extraction } \\ \text { USEPA } & \text { U.S. Environmental Protection Agency } \\ \text { USGS } & \text { U.S. Geological Survey } \\ \text { WWTP } & \text { wastewater-treatment plant }\end{array}$





\title{
Antibiotic, Pharmaceutical, and Wastewater-Compound Data for Michigan, 1998-2005
}

\author{
By Sheridan Kidd Haack
}

\section{Abstract}

Beginning in the late 1990's, the U.S. Geological Survey began to develop analytical methods to detect, at concentrations less than 1 microgram per liter $(\mu \mathrm{g} / \mathrm{L})$, emerging water contaminants such as pharmaceuticals, personal-care chemicals, and a variety of other chemicals associated with various human and animal sources. During 1998-2005, the U.S. Geological Survey analyzed the following Michigan water samples: 41 samples for antibiotic compounds, 28 samples for pharmaceutical compounds, 46 unfiltered samples for wastewater compounds (dissolved and suspended compounds), and 113 filtered samples for wastewater compounds (dissolved constituents only). The purpose of this report is to summarize the status of emerging contaminants in Michigan waters based on data from several different project-specific samplecollection efforts in Michigan during an 8-year period. During the course of the 8-year sampling effort, antibiotics were determined at 20 surface-water sites and 2 groundwater sites, pharmaceuticals were determined at 11 surface-water sites, wastewater compounds in unfiltered water were determined at 31 surface-water sites, and wastewater compounds in filtered water were determined at 40 surface-water and 4 groundwater sites. Some sites were visited only once, but others were visited multiple times. A variety of quality-assurance samples also were collected. This report describes the analytical methods used, describes the variations in analytical methods and reporting levels during the 8-year period, and summarizes all data using current (2009) reporting criteria. Very few chemicals were detected at concentrations greater than current laboratory reporting levels, which currently vary from a low of $0.005 \mu \mathrm{g} / \mathrm{L}$ for some antibiotics to $5 \mu \mathrm{g} / \mathrm{L}$ for some wastewater compounds. Nevertheless, 10 of 51 chemicals in the antibiotics analysis, 9 of 14 chemicals in the pharmaceuticals analysis, 34 of 67 chemicals in the unfiltered-wastewater analysis, and 56 of 62 chemicals in the filtered-wastewater analysis were detected. Antibiotics were detected at 7 of 20 tested surfacewater sites, but none were detected in 2 groundwater samples. Pharmaceuticals were detected at 7 of 11 surface-water sites. Wastewater compounds were detected at 25 of 31 sites for which unfiltered water samples were analyzed and at least once at all 40 surface-water sites and all 4 groundwater sites for which filtered water samples were analyzed.
Overall, the chemicals detected most frequently in Michigan waters were similar to those reported frequently in other studies nationwide. Patterns of chemical detections were site specific and appear to be related to local sources, overall land use, and hydrologic conditions at the time of sampling. Field-blank results provide important information for the design of future sampling programs in Michigan and demonstrate the need for careful field-study design. Fieldreplicate results indicated substantial confidence regarding the presence or absence of the many chemicals tested. Overall, data reported herein indicate that a wide array of antibiotic, pharmaceutical, and organic wastewater compounds occur in Michigan waters. Patterns of occurrence, with respect to hydrologic, land use, and source variables, generally appear to be similar for Michigan as for other sampled waters across the United States. The data reported herein can serve as a basis for future studies in Michigan.

\section{Introduction}

Manufactured and natural organic compounds such as pharmaceuticals, antibiotics, surfactants, flame retardants, plasticizers, steroids, and other trace organics that continue to be synthesized, used, and disposed of by modern society are now widely recognized as environmental contaminants (Daughton and Ternes, 1999; Halling-Sørensen, and others, 2002; Boxall and others, 2003). Detection capabilities for antibiotics, pharmaceuticals, and organic wastewater compounds (APOWCs) in the environment continue to be refined, and detection levels presently (2009) range from less than 1 nanogram per liter $(\mathrm{ng} / \mathrm{L})$ to a few micrograms per liter $(\mu \mathrm{g} / \mathrm{L})$ (Richardson, 2009). Very low detection capability and widespread occurrence have led to the documented presence of such compounds in water resources around the world. These detections have been associated with a variety of human and animal sources such as hospitals, septic tanks, wastewater effluents from treatment plants, urban runoff, and livestock wastes. Human and animal wastewater effluents are among the most important source pathways for the majority of these compounds into the aquatic environment (Ternes, 1998; Boxall and others, 2003; Paxeus, 2004; Glassmeyer and others, 2005; Lindqvist and others, 2005; Miao and others, 2005; 
Conn and others, 2006; Kinney and others, 2006; Reiner and others, 2007). Through a variety of environmental-exposure pathways, some APOWCs have been found in plant- and animal-tissue samples (Guenther and others, 2002; Delépée and others, 2004; Kinney and others, 2008; O'Toole and Metcalfe, 2006) and also in human-tissue samples (Hutter and others, 2005; Kurunthachalam and others, 2005).

While there is information on the effect some individual APOWCs may have on human or ecological health, much remains to be learned about the influence of low environmental concentrations of these chemicals, especially when present as complex mixtures (Richardson, 2009). In the United States, regulatory standards do not exist for the occurrence of most of these chemicals in the environment. Sample-collection, processing, and analysis methods have only been developed during the past 10 to 15 years, hampering the ability to consistently monitor for the presence of these compounds on regional or national scales (Focazio and others, 2004). Consequently, the occurrence data typically needed by regulators and policymakers to make informed resource-protection decisions is only now becoming widely available for many of these chemicals.

Recognizing the need for additional data at regional and national scales, the U.S. Geological Survey (USGS) developed some of the first analytical methods, continues to develop and refine methods for additional compounds, and implemented a series of national reconnaissance efforts targeting a broad suite of APOWCs with various potential uses and origins (e.g., pesticides, solvents, pharmaceuticals, personal-care products, etc.) in an array of environmental and hydrological settings across the United States. Some of these samples were collected in Michigan (Barnes and others, 2002; Kolpin and others, 2002; Focazio and others, 2008; Haack and others, 2009). In addition, the Michigan Department of Environmental Quality has supported the collection and analysis, by USGS and USGStrained personnel, of various types of APOWCs in several studies described later in this report. This report reviews and summarizes all USGS emerging-contaminant data for Michigan groundwater and surface water from 1998 to 2005.

\section{Purpose And Scope}

The purpose of this report is to describe the methods and results of USGS analyses of APOWCs in Michigan surface water and groundwater from 1998 to 2005. From 1998 to 2005, water samples were collected at 59 surface-water sites and 4 groundwater sites (fig. 1), as part of a variety of studies. Depending upon study design and purpose, some sites were sampled only once; others were sampled multiple times. The report summarizes analytical methods and reporting levels for antibiotics, pharmaceuticals, and wastewater compounds during the 8-year period and summarizes all data using current (2009) reporting criteria. The frequency of detection of antibiotics, pharmaceuticals, and wastewater compounds, and the spatial and temporal patterns of detections of these chemicals, are summarized in tables and figures throughout this report. Although the data included in this report were collected as part of various studies, taken together they provide a perspective on the occurrence and distribution of a variety of APOWCs in Michigan waters. Their summary here provides a basis for future study design and eventual historical comparisons.

\section{Sampling Procedures}

All water samples were collected by USGS personnel, or by USGS-trained personnel, using standard field protocols for ultra-clean sampling, preparation, preservation, and transportation to the laboratory. USGS standard sampling methods for water samples to be analyzed for the chemicals described in this report are documented in the USGS National Field Manual (NFM; http://water.usgs.gov/owq/FieldManual/). Among other considerations, the sampling methods for wastewater compounds, pharmaceuticals, and antibiotics (Wilde and others, 2004) proscribe the use or wearing of any of the chemicals to be analyzed; document that only sampling and processing equipment made of fluorocarbon polymers, glass, aluminum, or stainless steel should be used; specify the types of bottles (laboratory baked, brown glass) to be used for sample collection; and provide information on the proper cleaning and storing of sampling equipment. Surface-water samples were collected using grab-sampling methods, and groundwater samples were collected using standard USGS procedures (U.S. Geological Survey, 2006). For filtered water samples, standard USGS field-filtration procedures for organic chemicals were used (Wilde and others, 2004). For filtered water samples, a whole-water sample aliquot was passed through a 0.7 micrometer $(\mu \mathrm{m})$ pore-size, baked, glass-fiber filter in the field or office sample-preparatory area. Following collection and processing, samples were immediately chilled and shipped overnight to the appropriate laboratory.

\section{Analytical Procedures}

Three separate analytical procedures were used to assess detections and concentrations of the chemicals described in this report. Methods varied during the time covered by this report. Early data were provided on a provisional basis, with the understanding that method development was an ongoing process, and that compounds tested and compound-detection limits might change over time. All methods reported herein have been routinely evaluated and revised during the past several years as deemed appropriate. These evaluations include new information, insights, and focused studies on matrix interferences, laboratory and field contamination, and interlaboratory comparisons. Some compounds have been dropped from current (2009) versions of methods, owing to poor method recovery. Some of these compounds were reported in earlier USGS reports and other publications. 


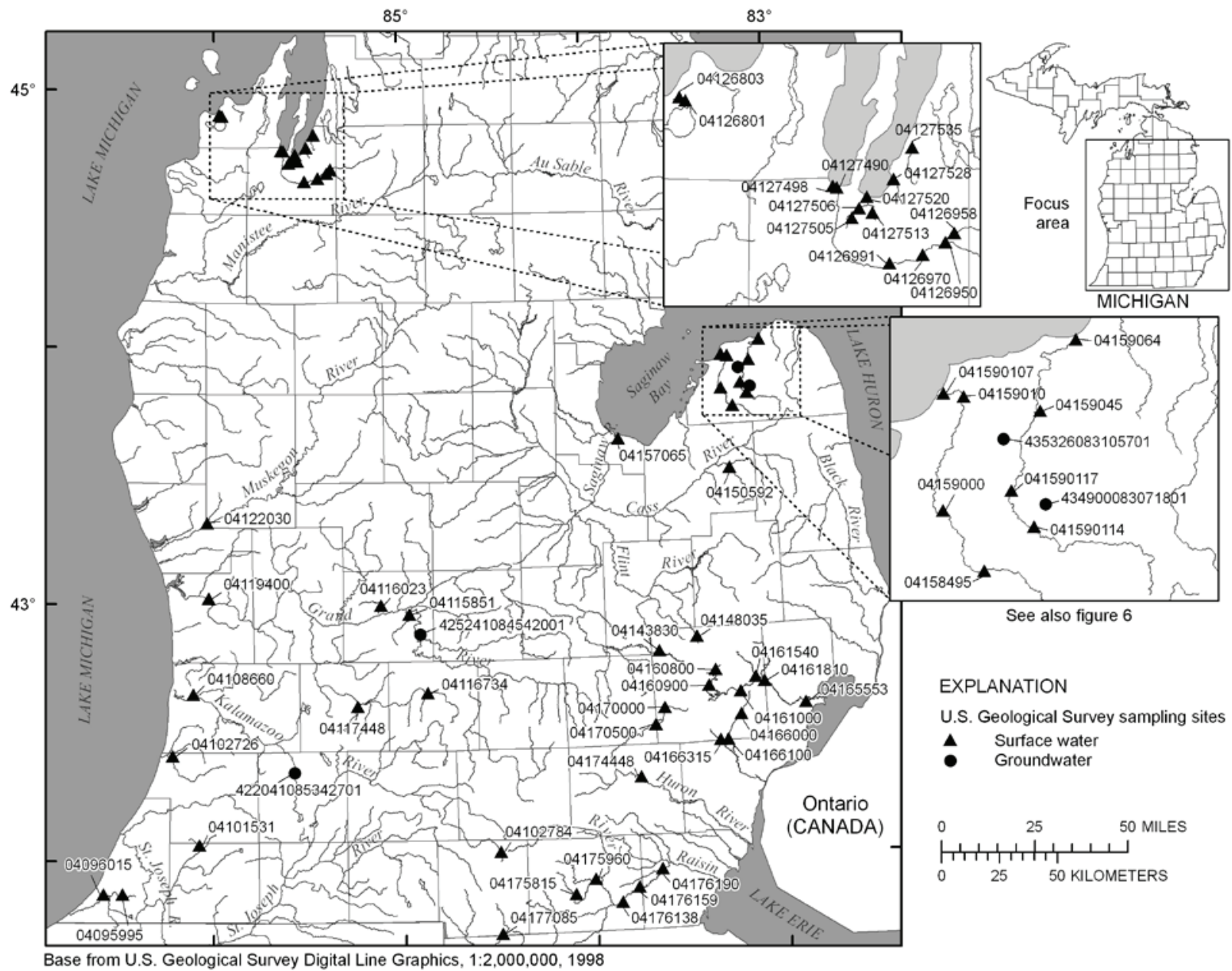

Figure 1. Map showing locations of sampling sites.

\section{Antibiotic Compounds}

Antibiotic compounds and selected antibiotic metabolites analyzed in filtered/unfiltered water samples, as well as reporting levels for these compounds, are identified in table 1. Antibiotic compounds were analyzed only on filtered water samples. Three samples collected in Michigan in 1999 were analyzed for 21 antibiotic compounds by off-line tandem solid-phase extraction (SPE) and single quadrupole, liquid chromatography/mass spectrometry positive-ion electrospray analysis (LC/MS-ESI $(+))$ using selected ion monitoring (SIM). Additional details on this method are provided else- where (Kolpin and others, 2002; Meyer and others, 2007). Two samples collected in Michigan in 2001 were analyzed for 24 antibiotic compounds using an on-line SPE LC/MS-ESI(+) method (Meyer and others, 2007). Since 2003, samples collected in Michigan have been analyzed for 39 to 49 antibiotic compounds using either the previous method, or an on-line SPE LC dual mass spectrometry (SPE LC/MS/MS) method modified from the on-line SPE LC/MS-ESI $(+)$ method of Meyer and others, 2007. 
Table 1. Names of antibiotic compounds and their current (2009) reporting levels.

[CAS, Chemical Abstract Service; RL, reporting level; NA, not applicable; all values in micrograms per liter]

\begin{tabular}{|c|c|c|}
\hline Name & CAS number & Current RL \\
\hline \multicolumn{3}{|c|}{ Beta-Lactams } \\
\hline Amoxicillin & $26787-78-0$ & 0.01 \\
\hline Ampicillin & $69-53-4$ & .01 \\
\hline Cefotaxime & $64485-93-4$ & .01 \\
\hline Cloxacillin & $61-72-3$ & .01 \\
\hline Oxacillin & $7240-38-2$ & .01 \\
\hline Penicillin G & $61-33-6$ & .01 \\
\hline Penicillin V & $87-08-1$ & .01 \\
\hline \multicolumn{3}{|c|}{ Macrolides } \\
\hline Erythromycin & $114-07-8$ & .005 \\
\hline Erythromycin- $\mathrm{H}_{2} \mathrm{O}$ (Anhydroerythromycin) ${ }^{1}$ & NA & .005 \\
\hline Azithromycin & $83905-01-5$ & .005 \\
\hline Roxithromycin & $80214-83-1$ & .005 \\
\hline Tylosin ${ }^{2}$ & $1401-69-0$ & .005 \\
\hline Virginiamycin $^{2}$ & $11006-76-1$ & .005 \\
\hline \multicolumn{3}{|c|}{ Quinolones } \\
\hline Ciprofloxacin & $85721-33-1$ & .005 \\
\hline Enrofloxacin $^{2}$ (no longer analyzed) & $93106-60-6$ & \\
\hline Clinafloxacin & $105956-97-6$ & .005 \\
\hline Flumequine & $42835-25-6$ & .005 \\
\hline Lomefloxacin & $98079-51-7$ & .005 \\
\hline Norfloxacin & $70458-96-7$ & .005 \\
\hline Ofloxacin & $83380-47-6$ & .005 \\
\hline Oxolinic Acid & $14698-29-4$ & .005 \\
\hline Sarafloxacin & $98105-99-8$ & .005 \\
\hline \multicolumn{3}{|c|}{ Sulfonamides } \\
\hline Sulfachlorpyridazine $^{2}$ & $80-32-0$ & .005 \\
\hline Sulfadiazine $^{2}$ & $68-35-9$ & .005 \\
\hline Sulfadimethoxine $^{2}$ & $122-11-2$ & .005 \\
\hline Sulfamerazine $^{2}$ (no longer analyzed) & $127-79-7$ & \\
\hline Sulfamethazine $^{2}$ & $57-68-1$ & .005 \\
\hline Sulfamethizole $^{2}$ (no longer analyzed) & $144-82-1$ & \\
\hline Sulfamethoxazole & $723-46-6$ & .005 \\
\hline Sulfathiazole $^{2}$ & $72-14-0$ & .005 \\
\hline \multicolumn{3}{|c|}{ Tetracyclines } \\
\hline Chlorotetracycline $^{2}$ & $57-62-5$ & .01 \\
\hline Anhydrochlorotetracycline ${ }^{1}$ & $13803-65-1$ & .01 \\
\hline Epi-anhydro-chlorotetracycline ${ }^{1}$ & $4497-08-9$ & .01 \\
\hline Epi-chlorotetracycline ${ }^{1}$ & $14297-93-9$ & .01 \\
\hline Iso-chlorotetracycline ${ }^{1}$ & $514-53-4$ & .01 \\
\hline Epi-iso-chlorotetracycline ${ }^{1}$ & NA & .01 \\
\hline Demeclocycline & $127-313-0$ & .01 \\
\hline Doxycycline & $564-25-0$ & .01 \\
\hline Minocycline (no longer analyzed) & $10118-90-8$ & \\
\hline
\end{tabular}


Table 1. Names of antibiotic compounds and their current (2009) reporting levels.-Continued

[CAS, Chemical Abstract Service; RL, reporting level; NA, not applicable; all values in micrograms per liter]

\begin{tabular}{lcc}
\multicolumn{1}{c}{ Name } & CAS number & Current RL $^{-}$ \\
\hline Oxytetracycline $^{2}$ & $79-57-2$ & 0.01 \\
Alpha apo-oxytetracycline $^{1}$ & $18695-01-7$ & .01 \\
Beta apo-oxytetracycline $^{1}$ & $18751-99-0$ & .01 \\
Epi-oxytetracycline $^{1}$ & $14206-58-7$ & .01 \\
Tetracycline & $64-75-5$ & .01 \\
Anhydrotetracycline $^{1}$ & $13803-65-1$ & .01 \\
Epi-anhydro-tetracycline $^{1}$ & $4465-65-0$ & .01 \\
Epi-tetracycline $^{1}$ & $23313-80-6$ & .01 \\
\hline & 0 ther & .005 \\
\hline Carbodox $^{2}$ & $15630-89-4$ & .005 \\
Lincomycin $^{2}$ & $154-21-2$ & .005 \\
Ormetoprim $^{2}$ & $6981-18-6$ & .005 \\
Trimethoprim $^{\prime}$ & $738-70-5$ & \\
\hline
\end{tabular}

${ }^{1}$ Degradation product of the parent compound.

${ }^{2}$ Primarily veterinary uses.

\section{Pharmaceutical Compounds}

Pharmaceutical compounds and selected pharmaceutical metabolites analyzed in filtered/unfiltered water samples, as well as reporting levels for these compounds, are identified in table 2. In 1999, the Methods Research and Development Program of the USGS National Water Quality Laboratory (NWQL) began the process of developing a method designed to identify and quantify human-health pharmaceuticals in filtered water (Cahill and others, 2004). A variety of compounds were evaluated in early methods development, but were subsequently dropped from the method for failure to satisfy long-term method-performance criteria. These compounds are identified in table 2 because previous USGS reports may have included data for these compounds. The current method identifies 14 compounds (12 pharmaceuticals and metabolites plus the antibiotics sulfamethoxazole and trimethoprim) using a chemically modified styrene-divinylbenzene resin-based SPE cartridge for analyte isolation and concentration and a high-performance liquid chromatography/mass spectrometry (HPLC/MS) system to separate the pharmaceuticals of interest from each other. Immediately following separation, the pharmaceuticals are ionized by electrospray ionization operated in the positive mode, and the positive ions produced are detected, identified, and quantified using a quadrupole mass spectrometer (Furlong and others, 2008).

\section{Wastewater Compounds}

Wastewater compounds analyzed from 1998 to 2005 are identified in table 3. Wastewater compounds were originally analyzed on unfiltered water samples, but more recently analyses for both filtered and unfiltered water samples have been made available. For water samples filtered in the field, disposable, polypropylene SPE cartridges containing a polystyrene-divinylbenzene phase are used to extract target compounds. Concentrated extracts are analyzed by capillarycolumn gas chromatography/mass spectrometry (GC/MS). The SPE method was used at the NWQL as a conditional method starting January 1, 2001, and was officially approved and implemented at the NWQL on June 27, 2001. Further information on this method can be found in Zaugg and others (2002).

A method that uses continuous liquid-liquid extraction (CLLE) instead of SPE for sample preparation for unfiltered water samples was implemented at the NWQL in October 1998 on a custom basis. This method was approved for unfiltered water samples in June 2006. Further information on the method for unfiltered water samples is available in Zaugg and others (2006).

A comparison of results for more than 30 environmental samples between the CLLE and the SPE methods demonstrated that concentrations for hydrophobic (low-water solubility) compounds were much less (up to 400 percent) when determined by SPE because of sample filtration, whereas results for hydrophilic compounds were identical. Therefore, detection limits and constituents reported vary between the two methods (table 4), and reporting levels for both methods have varied over time. Application of the SPE method provides data for dissolved wastewater compounds to supplement whole-water CLLE data used to identify wastewater constituents in samples such as sanitary- or storm-sewer waters or animal waste. 
Table 2. Names of pharmaceutical compounds, their uses, and their current (2009) and 1999 reporting levels.

[CAS, Chemical Abstract Service; RL, reporting level; --, not analyzed; E, concentrations are always qualified as estimated; NA, not available; all values in micrograms per liter]

\begin{tabular}{|c|c|c|c|c|}
\hline Name & CAS number & Use & Current RL & 1999 RL \\
\hline 1,7-Dimethylxanthine & $611-59-6$ & Caffeine metabolite & 0.10 & 0.018 \\
\hline Acetaminophen & $103-90-2$ & Analgesic & .08 & .009 \\
\hline Carbamazepine & $298-46-4$ & Epilepsy treatment & .04 & -- \\
\hline Cimetidine (no longer analyzed) & $51481-61-9$ & Stomach acid reducer & & .007 \\
\hline Dehydronifedipine & $67035-22-7$ & Metabolite nifedipine, a vasodilator & .06 & .01 \\
\hline Digoxigenin (no longer analyzed) & $1672-46-4$ & Cardiac regulation & & .008 \\
\hline Digoxin (no longer analyzed) & $20830-75-5$ & Cardiac regulation & & .26 \\
\hline Diltiazem & $42399-41-7$ & Angina medication & E.04 & .012 \\
\hline Fluoxetine (no longer analyzed) & $54910-89-3$ & Antidepressant & & .018 \\
\hline Gemfibrozil (no longer analyzed) & $25812-30-0$ & Lipid/cholesterol regulator & & .015 \\
\hline Ibuprofen (no longer analyzed) & $15687-27-1$ & Analgesic & & .018 \\
\hline Metformin (no longer analyzed) & $657-24-9$ & Glycemic control & & .003 \\
\hline $\begin{array}{l}\text { Paroxetine metabolite(no longer } \\
\text { analyzed) }\end{array}$ & NA & Caffeine metabolite & & .26 \\
\hline Ranitidine (no longer analyzed) & $66357-35-5$ & Stomach acid reducer & & .01 \\
\hline Albuterol (Salbutamol) & $18559-94-9$ & Bronchodilator & .04 & .029 \\
\hline Sulfamethoxazole & $723-46-6$ & Antibiotic & .10 & .023 \\
\hline
\end{tabular}


Table 3. Names of wastewater-method compounds and their possible uses or sources.

[CAS, Chemical Abstract Service; NA, not applicable; PAH, polycyclic aromatic hydrocarbon]

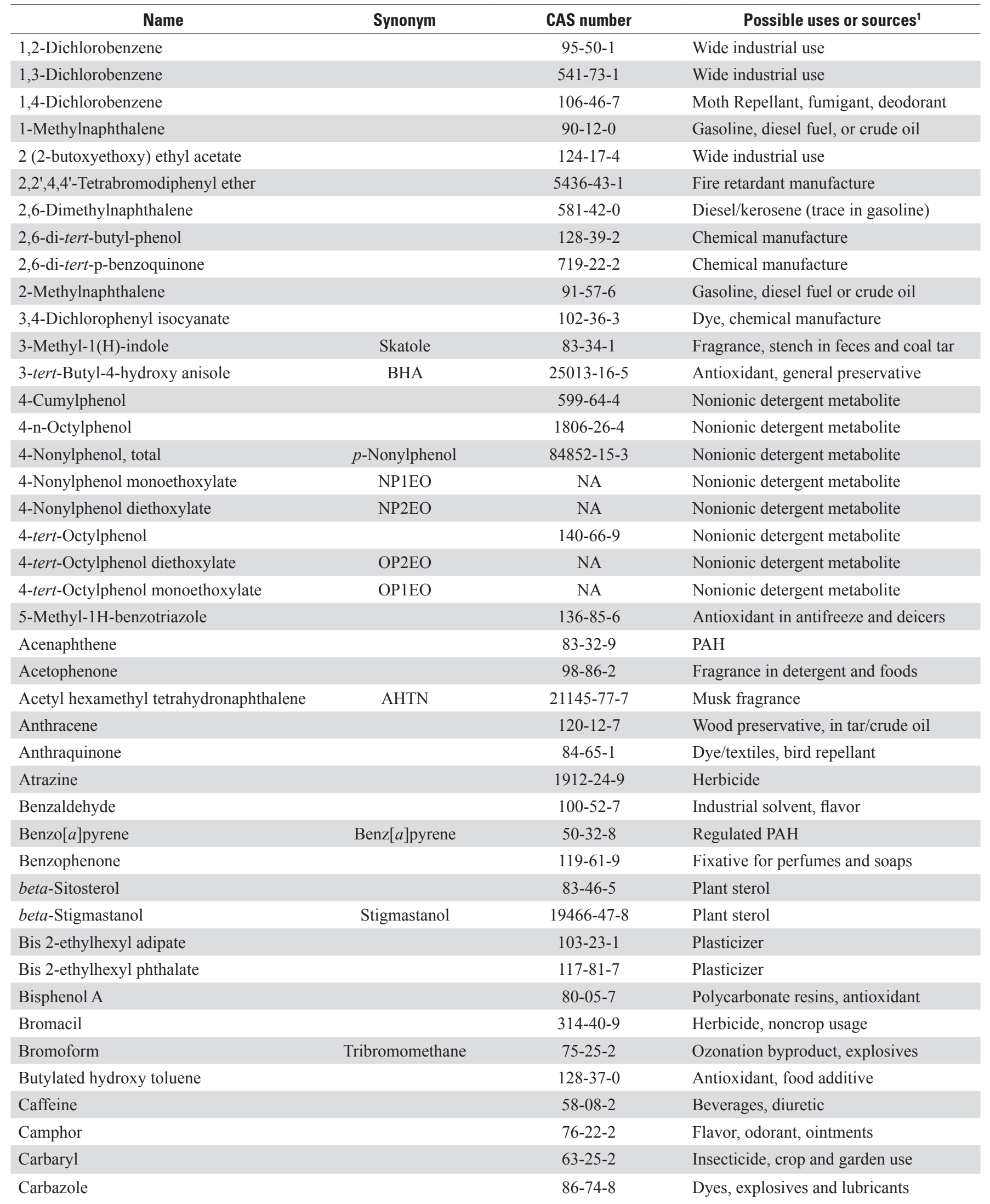


Table 3. Names of wastewater-method compounds and their possible uses or sources.-Continued

[CAS, Chemical Abstract Service; NA, not applicable; PAH, polycyclic aromatic hydrocarbon]

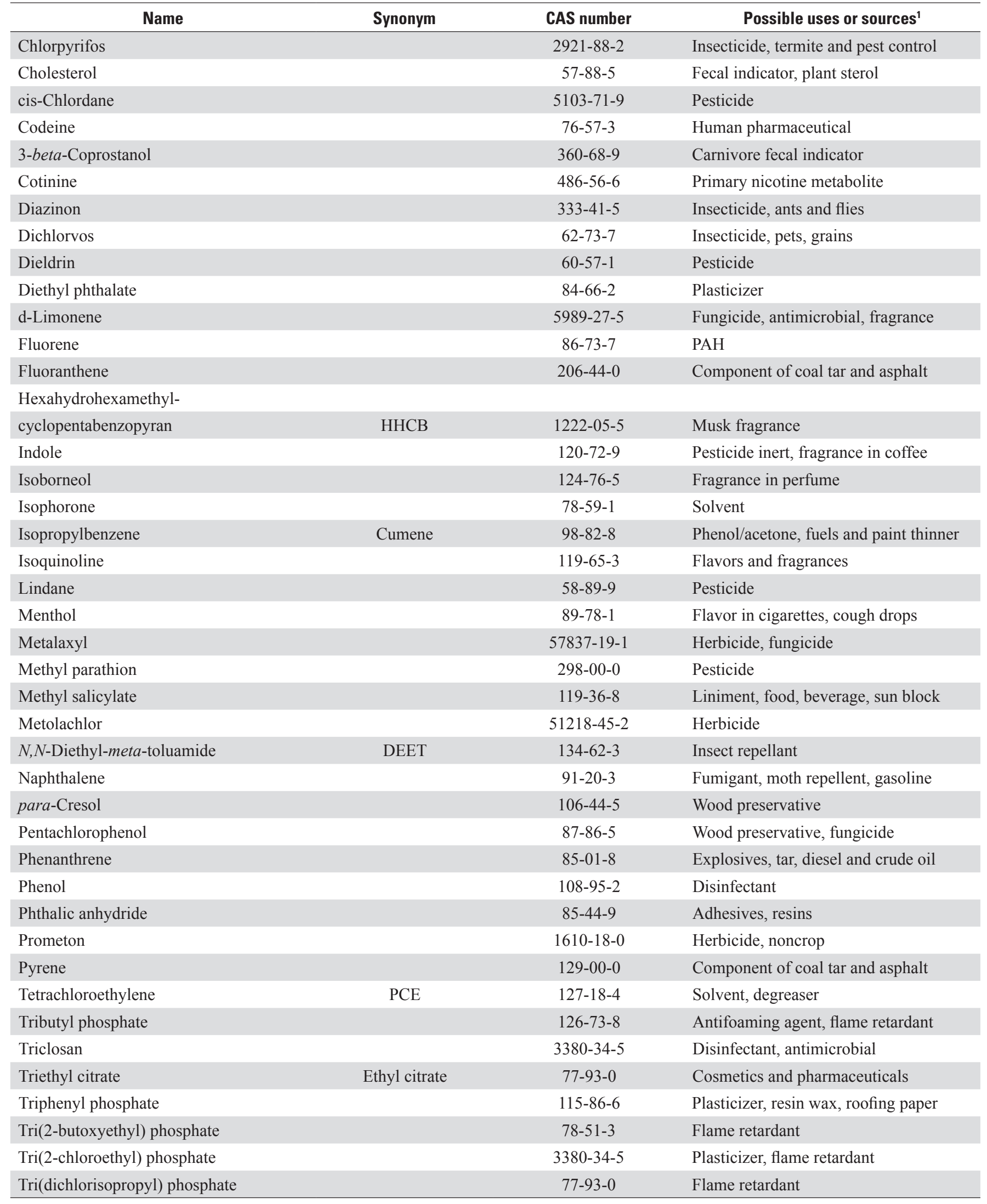

\footnotetext{
${ }^{1}$ From Zaugg and others, 2002.
} 
Table 4. Names of wastewater-method compounds and their reporting-level variations among filtered and unfiltered analyses, over time.

[RL, reporting level; E, concentration is always estimated; all values in micrograms per liter]

\begin{tabular}{|c|c|c|c|c|}
\hline \multirow[b]{2}{*}{ Name } & \multirow{2}{*}{$\begin{array}{l}\text { Filtered water } \\
\text { current } \\
\text { (2009) } \\
\text { RL }\end{array}$} & \multicolumn{3}{|c|}{ Unfiltered water } \\
\hline & & $\begin{array}{c}\text { Current } \\
\text { (2009) } \\
\text { RL }\end{array}$ & $\begin{array}{c}1999 \\
\text { RL }\end{array}$ & $\begin{array}{c}2001 \\
\mathrm{RL}\end{array}$ \\
\hline 1,2-Dichlorobenzene (no longer analyzed) & & & 0.03 & \\
\hline 1,3-Dichlorobenzene (no longer analyzed) & & & .03 & \\
\hline 1,4-Dichlorobenzene & 0.5 & 0.2 & .03 & 0.5 \\
\hline \multicolumn{5}{|l|}{$17 \alpha$-ethynyl estradiol (deleted from analysis) } \\
\hline $17 \alpha$-estradiol (deleted from analysis) & & & .5 & \\
\hline 1-Methylnaphthalene & .5 & .2 & & .5 \\
\hline 2 (2-butoxyethoxy) ethyl acetate (no longer analyzed) & & & .06 & \\
\hline $2,2^{\prime}, 4,4^{\prime}$-Tetrabromodiphenyl ether & & .2 & & \\
\hline 2,6-Dimethylnaphthalene & .5 & .2 & .09 & .5 \\
\hline 2,6-di-tert-butyl-phenol (no longer analyzed) & & & .09 & \\
\hline 2,6-di-tert-p-benzoquinone (no longer analyzed) & & & .07 & \\
\hline 2-Methylnaphthalene & .5 & .2 & & .5 \\
\hline 3,4-Dichlorophenyl isocyanate & & 2 & & \\
\hline 3-Methyl-1(H)-indole (Skatole) & 1 & .2 & & 1 \\
\hline 3-tert-Butyl-4-hydroxy anisole (BHA) & E 5 & .2 & .12 & 5 \\
\hline 4-Cumylphenol & 1 & .2 & & 1 \\
\hline 4-n-Octylphenol & 1 & .2 & & 1 \\
\hline 4-Nonylphenol (total) (branched) & E 5 & 1.6 & .5 & 5 \\
\hline 4-Nonylphenol diethoxylate, (sum of all isomers) & E 5 & 3.2 & 1.1 & 5 \\
\hline 4-Nonylphenol monoethoxylate, (sum of all isomers) & & 2 & 1 & \\
\hline 4-tert-Octylphenol & 1 & .2 & & 1 \\
\hline 4-tert-Octylphenol diethoxylate & E 1 & 1 & .2 & 1 \\
\hline 4-tert-Octylphenol monoethoxylate & E 1 & .3 & .1 & 1 \\
\hline 5-Methyl-1H-benzotriazole & 2 & 1.6 & & 2 \\
\hline Acenaphthene (no longer analyzed) & & & .04 & \\
\hline Acetophenone & .5 & .3 & .1 & 2 \\
\hline Acetyl hexamethyl tetrahydronaphthalene (AHTN) & .5 & .2 & & .5 \\
\hline Anthracene & .5 & .2 & .05 & .5 \\
\hline Anthraquinone & .5 & .2 & & .5 \\
\hline Atrazine & & .2 & & \\
\hline Benzaldehyde (no longer analyzed) & & & .10 & \\
\hline Benzo $[a]$ pyrene & 0.5 & .2 & .05 & .5 \\
\hline Benzophenone & .5 & .2 & & .5 \\
\hline beta-Sitosterol & E 2 & .8 & & 2 \\
\hline beta-Stigmastanol & E 2 & .8 & & 2 \\
\hline Bis 2-ethylhexyl adipate (no longer analyzed) & & & 1.5 & \\
\hline Bis 2-ethylhexyl phthalate & & 2 & 2 & \\
\hline Bisphenol A & 1 & .4 & .09 & 1 \\
\hline Bromacil & .5 & .2 & & .5 \\
\hline Bromoform & E. 5 & .2 & & \\
\hline
\end{tabular}


Table 4. Names of wastewater-method compounds and their reporting-level variations among filtered and unfiltered analyses, over time.-Continued

[RL, reporting level; E, concentration is always estimated; all values in micrograms per liter]

\begin{tabular}{|c|c|c|c|c|}
\hline \multirow[b]{2}{*}{ Name } & \multirow{2}{*}{$\begin{array}{l}\text { Filtered water } \\
\text { current } \\
\text { (2009) } \\
\text { RL }\end{array}$} & \multicolumn{3}{|c|}{ Unfiltered water } \\
\hline & & $\begin{array}{c}\text { Current } \\
\text { (2009) } \\
\text { RL }\end{array}$ & $\begin{array}{c}1999 \\
\text { RL }\end{array}$ & $\begin{array}{c}2001 \\
\mathrm{RL}\end{array}$ \\
\hline Butylated hydroxy toluene (no longer analyzed) & & & .08 & \\
\hline Caffeine & .5 & .2 & .08 & .01 \\
\hline Camphor & .5 & .2 & & .5 \\
\hline Carbaryl & E 1 & .2 & .06 & 1 \\
\hline Carbazole & .5 & .2 & & \\
\hline Chlorpyrifos & .5 & .2 & .02 & .5 \\
\hline Cholesterol & E 2 & .8 & 1.5 & 2 \\
\hline cis-Chlordane (no longer analyzed) & & & .04 & \\
\hline Codeine (no longer analyzed) & & & .1 & \\
\hline 3-beta-Coprostanol & E 2 & .8 & 6 & 2 \\
\hline Cotinine & 1 & .8 & & \\
\hline Diazinon & .5 & .2 & .03 & .5 \\
\hline Dichlorvos (deleted from filtered water analysis) & & .2 & & 1 \\
\hline Dieldrin (no longer analyzed) & & & .08 & \\
\hline Diethyl phthalate & & .2 & & \\
\hline d-Limonene & E. 5 & .2 & & .5 \\
\hline \multicolumn{5}{|l|}{ Equilenin (deleted from analysis) } \\
\hline \multicolumn{5}{|l|}{ Estrone (deleted from analysis) } \\
\hline Fluoranthene & .5 & .2 & .03 & .5 \\
\hline \multicolumn{5}{|l|}{ Fluorene (no longer analyzed) } \\
\hline Hexahydrohexamethylcyclopentabenzopyran (HHCB) & .5 & .2 & & .5 \\
\hline Indole & .5 & .2 & & .5 \\
\hline Isoborneol & .5 & .2 & & .5 \\
\hline Isophorone & .5 & .2 & & .5 \\
\hline Isopropylbenzene & E .5 & .2 & & .5 \\
\hline Isoquinoline & .5 & .2 & & .5 \\
\hline Lindane (no longer analyzed) & & & .05 & \\
\hline Menthol & .5 & .2 & .05 & .5 \\
\hline Metalaxyl & .5 & .2 & & .5 \\
\hline Methyl parathion (no longer analyzed) & & & .06 & \\
\hline Methyl salicylate & .5 & .2 & & .5 \\
\hline Metolachlor & .5 & .2 & & .5 \\
\hline$N, N$-diethyl-meta-toluamide (DEET) & .5 & .2 & & .5 \\
\hline Naphthalene & .5 & .2 & .03 & .5 \\
\hline para-Cresol & 1 & .2 & .03 & 1 \\
\hline Pentachlorophenol & E 2 & .8 & & 2 \\
\hline Phenanthrene & .5 & .2 & .06 & .5 \\
\hline Phenol & .5 & .2 & .08 & 2 \\
\hline Phthalic anhydride (no longer analyzed) & & & .15 & \\
\hline Prometon & .5 & .2 & & \\
\hline
\end{tabular}


Table 4. Names of wastewater-method compounds and their reporting-level variations among filtered and unfiltered analyses, over time.-Continued

[RL, reporting level; E, concentration is always estimated; all values in micrograms per liter]

\begin{tabular}{|c|c|c|c|c|}
\hline \multirow[b]{2}{*}{ Name } & \multirow{2}{*}{$\begin{array}{l}\text { Filtered water } \\
\text { current } \\
(2009) \\
\text { RL }\end{array}$} & \multicolumn{3}{|c|}{ Unfiltered water } \\
\hline & & $\begin{array}{c}\text { Current } \\
\text { (2009) } \\
\text { RL }\end{array}$ & $\begin{array}{c}1999 \\
\text { RL }\end{array}$ & $\begin{array}{c}2001 \\
\mathrm{RL} \\
\end{array}$ \\
\hline Pyrene & .5 & .2 & .03 & .5 \\
\hline Tetrachloroethylene & E.5 & .4 & .03 & .5 \\
\hline Tributyl phosphate & .5 & .2 & & .5 \\
\hline Triclosan & 1 & .2 & .04 & 1 \\
\hline Triethyl citrate (ethyl citrate) & .5 & .2 & & .5 \\
\hline Triphenyl phosphate & .5 & .2 & .1 & .5 \\
\hline Tris(2-butoxyethyl)phosphate & E.5 & .2 & & \\
\hline Tris(2-chloroethyl)phosphate & .5 & .2 & .04 & .5 \\
\hline Tris(dichlorisopropyl)phosphate & .5 & .2 & .1 & .5 \\
\hline
\end{tabular}

\section{Qualitative Identification Criteria and Reporting Levels}

The three analytical methods used in this report share a common rationale for compound identification and quantification, despite differences in specific analytical details. All rely on the application of mass-spectrometric techniques, which provides compound-specific fragments that, when coupled with chromatographic-retention characteristics, produce unambiguous identification of each compound. In addition, the specific criteria for the identification of each compound are based upon analysis of authentic standards for all compounds (Zaugg and others, 2006; Meyer and others, 2007: Furlong and others, 2008).

For antibiotic compounds, analyzed at the USGS Organic Research Laboratory in Lawrence, Kansas, only concentrations equal to or above the minimum reporting level (MRL) for each compound are reported. Reporting levels for antibiotic compounds for each method are equal to the limit of quantitation (signal-to-noise ratios of 5 to 10 times above background) for the method. In this report, all concentrations of antibiotic compounds are reported using the reporting criteria appropriate at the time, since the method of determining antibiotic reporting levels has not changed. However, the use of different analytical methods for the same compounds has resulted in varying compound-reporting levels from 1998 to 2008. The most recent analytical method offers the lowest reporting levels $(0.005-0.01 \mu \mathrm{g} / \mathrm{L}$; table 1$)$; previous reporting levels ranged from 0.05 to $0.10 \mu \mathrm{g} / \mathrm{L}$ for analytical methods used through 2003.
Wastewater and pharmaceutical compounds were analyzed at the USGS NWQL. Historically, the NWQL used MRLs when reporting data. For wastewater compounds, initial MRLs were set higher (two to five times for most compounds) than initial method detection limits (MDLs) calculated according to the then-current U.S. Environmental Protection Agency (USEPA) protocol, (U.S. Environmental Protection Agency 1997). For pharmaceutical compounds, MDLs were likewise calculated using USEPA procedures (U.S. Environmental Protection Agency, 1997, 2005).

The NWQL currently (2009) uses a statistic called the long-term method detection limit (LT-MDL; Bonn, 2008), which is similar to the current (2009) USEPA MDL (U.S. Environmental Protection Agency, 2005), and is determined on an annual basis for each compound. The LT-MDL is statistically defined as identical to the USEPA-MDL: the smallest measured concentration that can be reported with 99-percent confidence that the concentration of the compound is greater than zero, and there is less than a 1-percent chance of a false-positive determination. Like the USEPA-MDL, it is obtained from replicate analyses of spiked blank water; therefore, it applies to uncomplicated samples. It differs from the USEPA-MDL in that it incorporates variability owing to different instruments and analysts and is calculated over an extended period of time. This means that MDLs, and MRLs calculated from MDLs, may change over time.

In conjunction with the LT-MDL, NWQL currently (2009) uses a laboratory reporting level (LRL) that replaces the MRL. Similar to the MRL, the LRL is set higher than the LT-MDL. Further, LRLs may change over time if LT-MDLs are revised after annual reviews. 
Currently (2009), the NWQL reports without qualification most analytical results greater than the LT-MDL (Bonn, 2008). These results can be considered detected (different from zero with 99-percent confidence) if the sample matrix has no interfering properties. Historically and currently (2009), if no LT-MDL (and associated LRL) has been established, the NWQL reports without qualification all analytical results greater than the MRL. Analytical results less than the LT-MDL, or MRL prior to conversion to the LT-MDL, are reported with qualification if the analytical method includes compound-specific identification-usually a matching spectral signature - such as for the compounds discussed in this report. Results less than the LT-MDL or historically, the MRL, are reported with a qualifying $\mathrm{E}$ (estimated) or $\mathrm{M}$ (detected but not quantified) code. The $\mathrm{E}$ code signifies that the reported compound concentration has greater relative uncertainty than if the concentration exceeded the LT-MDL or MRL. Results less than the LT-MDL or MRL that can be rounded to zero at the order of magnitude reported for a given constituent are reported with an $\mathrm{M}$ code. For example, a concentration of $0.04 \mu \mathrm{g} / \mathrm{L}$ would receive an $\mathrm{M}$ code for a constituent for which the LT-MDL or MRL is $0.1 \mu \mathrm{g} / \mathrm{L}$ or an E code for a constituent for which the LT-MDL or MRL is $0.06 \mu \mathrm{g} / \mathrm{L}$, but would receive no qualification for a constituent for which the LTMDL or MRL is $0.01 \mu \mathrm{g} / \mathrm{L}$. Compounds that are not detected are reported as less than the LRL. Concentrations of some compounds are always reported as estimated owing to variable performance. Pharmaceutical and wastewater compounds for which estimated concentrations are always reported are indicated in tables 2 and 4.

Reporting levels for many compounds changed during 1998-2008. In addition, some compounds either were removed or added to analysis suites during 1998-2008. Tables 2 and 4 show that some previous pharmaceutical and wastewater-compound reporting levels were lower than current (2009) levels. Concentrations lower than those currently considered reliable for these methods may have been reported previously in USGS and other publications. In this report, previously reported concentrations less than current (2009) reporting levels have been recensored using current reporting criteria to provide consistent information. In addition, data for compounds removed from analytical methods are not included in this report, even though data for such compounds may have appeared in previous USGS or other publications.

\section{Quality Assurance And Quality Control}

Several quality-control sample types are required to properly interpret ambient environmental concentrations of pharmaceutical, antibiotic and wastewater compounds in aqueous samples. The quality-control sample types include field blanks, replicate environmental samples, and matrixspike recovery samples. Matrix-spike materials were not generally available prior to 2005 ; no matrix-spike samples were analyzed.
Field blanks characterize the likelihood of positive bias or contamination owing to field and laboratory handling. Field blanks consisted of laboratory-grade organic-free water that was processed in the field and laboratory in the same manner as environmental samples. Field blanks were submitted for about 2 percent ( 1 for 41 environmental samples) of the samples analyzed for antibiotics, 10 percent ( 3 for 28 environmental samples) of the samples analyzed for pharmaceuticals, and 10 percent (12 for 113 environmental samples) of the filtered water samples analyzed for wastewater compounds. However, no field blanks were collected for the 46 unfiltered environmental samples analyzed for wastewater constituents. Teflon is the recommended composition of containers for collection of APOWC samples. High-density polyethylene (HDPE) is a common container composition for collection of many other types of water samples. To determine the effect of container composition on wastewater analytes, one field blank was collected in a high-density polyethylene (HDPE) container (HDPE Blank, table A4), whereas all other field blanks were collected in Teflon containers. One equipment blank (Filter Blank, table A4) was collected in the following manner. Organic-free water was spiked with an artificial sample of wastewater compounds at known concentrations. In the laboratory, this spiked water was passed through the filtration apparatus as though it was a routine sample. The filtration apparatus was then cleaned according to established protocols, and a subsequent "sample" of organic-free water was processed through the filter. This sample was sent for analysis for the purpose of establishing that the cleaning procedure adequately removed any contamination.

Replicate samples are used to characterize the amount of variability associated with sample collection, processing, and analysis. Replicate field samples were collected once for antibiotic compounds, twice for pharmaceutical compounds, and nine times for wastewater compounds. Replicate samples identify the variation that may be associated with compound concentrations, owing to any step of sample collection or analysis.

\section{Antibiotics}

Results of antibiotic analyses for 41 environmental samples and 1 field blank are reported in table A1. No antibiotics were detected in the field blank sample. On August 9, 2006, a field replicate was collected at the Clinton River at Auburn Hills, Mich. Five antibiotics were detected in the primary environmental sample, but one additional antibiotic - azithromycin — was detected in the replicate sample. Otherwise, there was agreement regarding detection of the five antibiotics common to both samples. The pharmaceuticals method also was performed on three of these environmental samples (Boardman River at Traverse City, June 16, 1999; Huron River near Ann Arbor, September 10, 2001; and River Raisin near Deerfield, September 11, 2001). Therefore, results for the two antibiotics (sulfamethoxazole and trimethoprim) 
analyzed by the pharmaceuticals method can be compared with results from the antibiotics method. Sulfamethoxazole was not reported for any of these samples by either method. Trimethoprim was reported for the Boardman River sample by the pharmaceuticals method but not by the antibiotics method. This result likely reflects the lower reporting limit for the pharmaceuticals method for this compound.

\section{Pharmaceuticals}

Results of pharmaceutical analyses for 28 environmental samples and 3 field blanks are reported in table A2. No pharmaceuticals were detected in any field-blank sample. Two field-replicate samples were collected. Only caffeine was detected in both the primary environmental sample and the associated replicate sample collected on June 15, 2004. For the field-replicate sample collected on November 17, 2004, carbamazepine and cotinine were detected in both the primary environmental sample and the associated replicate sample. For three additional samples, laboratory-replicate analyses were provided. These replicates exhibited general agreement among the primary environmental samples and the associated replicate samples regarding compounds detected and concentrations estimated.

\section{Wastewater Compounds}

The range of compound groups in the wastewater method includes potential contaminant sources from chemicals commonly used by field and laboratory personnel in their personal as well as professional lives and from the equipment used to collect, process, and analyze the samples. Unlike antibiotics and pharmaceuticals, several wastewater compounds were detected in field blanks. In addition, some wastewater-chemical results were inconsistent among primary environmental samples and associated replicate samples. The quality-assurance data for wastewater compounds must be carefully taken into account in interpretation of wastewater-chemical occurrence and concentration. Results of wastewater-compound analyses for 46 unfiltered water samples are reported in table A3 and results for 113 filtered water samples are reported in table A4.

\section{Field Blanks}

Although some wastewater compounds were detected in field blanks, the majority of the wastewater compounds analyzed were not detected in any field blank in this study. Table 5 lists all of the wastewater compounds detected in field and equipment blanks analyzed in this study. Many of the constituents detected in blanks are the same as those detected in more than 5 percent of USGS field blanks from across the country (Zaugg and Leiker, 2006; table 5). The USGS NWQL considers occurrence of compounds in 10 percent or more field blanks to be evidence of chronic contamination. Since only 13 field and equipment blanks were collected, detection of a compound in even 1 blank results in an occurrence level near 10 percent; therefore, occurrence results for the compounds in environmental samples, shown in table 5 , should be viewed with caution. However, there were some differences in the probable significance of these compounds as revealed by comparing detection frequencies for the compounds in blanks, overall environmental samples, and paired environmental samples. Paired environmental samples were those samples collected on the same date as the field blank and immediately preceding or following blank processing. Some of the compounds reported in table 5 occurred in blanks and overall environmental samples with similar frequencies and at equivalent concentrations. For example, 1,4-dichlorobenzene occurred in the majority of blanks, overall environmental samples, and paired environmental samples. Phenol contamination also was prevalent. Data for these two constituents indicate pervasive contamination at some sample-processing step. However, caffeine was detected in only one field blank at an unquantifiable concentration and was never detected in a paired environmental sample, but was present in approximately one-half of environmental samples and occasionally at reliably quantified concentrations. Caffeine occurrence in blanks may be reflective of random contamination.

Only two constituents - the ubiquitous field-blank contaminants 1,4-dichlorobenzene and phenol-were detected in the equipment blank that was processed using Teflon, glass, and stainless-steel containers (Filter Blank, table A4). Other than the HDPE Field Blank (HDPE Field Blank, table A4), all other field blanks were collected in Teflon containers. Nine wastewater constituents were detected in the blank processed in the HDPE container; however, 11 constituents were detected in a Field Blank collected on October 28, 2004, and 8 constituents were detected in 2 additional Field Blanks (June 15, 2004 and November 22, 2005). The constituents detected in the HDPE Field Blank also were detected in other (Teflon container) field blanks. These results do not indicate any particular contamination effect arising from use of HDPE plastic as opposed to Teflon containers.

\section{Replicates}

Nine replicate pairs of samples were analyzed for 62 wastewater compounds (table A4). These 9 replicate analyses produced 531 consistent results, which indicated the compound was either absent or present in both replicates. There were 92 samples for which a given compound was reported as present in both the primary sample and the replicate. For 88 of these instances, the indicated concentration was either $\mathrm{M}$ or the identical estimated value in both samples. In the remaining 4 instances, there were two cases where one sample had an estimated value and the other was coded "M," and there were two cases where two different estimated values were given. In the latter two cases, the estimated values were different by only $0.1 \mu \mathrm{g} / \mathrm{L}$. These results indicate substantial agreement between replicate samples; however, there were 27 instances 
Table 5. Compounds detected in field and equipment blanks.

[ $\mu \mathrm{g} / \mathrm{L}$, micrograms per liter; NA, not applicable; E, concentrations are estimated; M, detected but not quantified]

\begin{tabular}{|c|c|c|c|c|c|c|}
\hline Compound & $\begin{array}{l}\text { Number } \\
\text { of blank } \\
\text { samples }\end{array}$ & $\begin{array}{l}\text { Detection in } \\
\text { blanks } \\
\text { (percent) }\end{array}$ & $\begin{array}{l}\text { Detection in } \\
\text { overall } \\
\text { environmental } \\
\text { samples } \\
\text { (percent) }\end{array}$ & $\begin{array}{c}\text { Detection } \\
\text { in paired }^{\text {a }} \\
\text { samples } \\
\text { (percent) }\end{array}$ & $\begin{array}{c}\text { Highest } \\
\text { concentration } \\
\text { in blanks } \\
(\mu \mathrm{g} / \mathrm{L})\end{array}$ & $\begin{array}{c}\text { Highest } \\
\text { concentration } \\
\text { in samples } \\
(\mu \mathrm{g} / \mathrm{L})\end{array}$ \\
\hline Antibiotics & 1 & 0 & variable & NA & NA & variable \\
\hline Parmaceuticals & 3 & 0 & variable & NA & NA & variable \\
\hline \multicolumn{7}{|c|}{ Wastewater compounds } \\
\hline 1,4-Dichlorobenzene $\mathrm{e}^{\mathrm{b}}$ & 13 & 92 & 72 & 82 & E 0.1 & E 0.3 \\
\hline 1-Methylnaphthalene & 13 & 23 & 34 & 18 & M & E.1 \\
\hline 2-Methylnaphthalene & 13 & 23 & 38 & 18 & E.1 & E.1 \\
\hline Acetophenone & 13 & 8 & 10 & 0 & E.4 & E. 2 \\
\hline Benzophenone & 13 & 23 & 52 & 9 & E.1 & E. 3 \\
\hline Bisphenol A & 9 & 11 & 19 & 0 & $\mathrm{M}$ & M \\
\hline Caffeine & 13 & 8 & 52 & 0 & M & .7 \\
\hline Isophorone & 13 & 31 & 42 & 9 & M & 3.1 \\
\hline Menthol & 13 & 15 & 23 & 9 & M & E. 2 \\
\hline$N, N$-diethyl-meta-toluamide (DEET) & 13 & 31 & 69 & 18 & E.1 & E. 3 \\
\hline Naphthalene & 13 & 31 & 36 & 9 & E.4 & E.1 \\
\hline Nonylphenol diethoxylate & 13 & 8 & 23 & 0 & E 8 & E 8 \\
\hline para-Nonylphenol (total) & 13 & 8 & 19 & 0 & M & E 2 \\
\hline Phenanthrene & 13 & 8 & 26 & 9 & M & M \\
\hline Phenol & 13 & 54 & 39 & 45 & 1.2 & 1.6 \\
\hline Tributyl phosphate & 13 & 15 & 34 & 9 & E.1 & E. 2 \\
\hline Triphenyl phosphate & 13 & 15 & 32 & 9 & E.1 & E.1 \\
\hline Tris(2-chloroethyl)phosphate & 13 & 15 & 30 & 9 & E.1 & E.1 \\
\hline Tris(dichlorisopropyl)phosphate & 13 & 8 & 23 & 0 & E.1 & E.2 \\
\hline
\end{tabular}

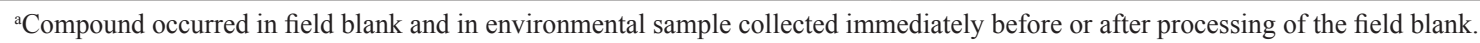

${ }^{\mathrm{b} C}$ Constituents in bold reported in more than 5 percent of field blanks nationwide since August 2004 (Zaugg and Leiker, 2006).

in which replicate analyses did not report the same result for a compound. For 26 of these instances, the compound was reported as not being present (concentration less than the reporting level) in one sample, but present with either an $\mathrm{M}$ or E qualifier in the replicate sample. For the remaining sample pair, phenol was reported as $<0.5 \mu \mathrm{g} / \mathrm{L}$ in one sample, but present at $0.6 \mu \mathrm{g} / \mathrm{L}$ in the replicate sample. Five compounds reported in blanks (acetophenone, benzophenone, caffeine, phenol, and tributyl phosphate) accounted for 9 of the 25 inconsistent replicate-pair results, leaving 16 inconsistent results for compounds that did not occur in field blanks.

Discrepancies in results for a primary sample and its replicate may arise when concentrations are near the LT-MDL. Data for caffeine shed some light on how to interpret replicate analyses in which one replicate sample indicates a compound was not detected, and the other indicates a very low, usually estimated concentration of the constituent. There were
18 environmental samples for which caffeine was analyzed by two different methods: the wastewater method and a pesticide method providing concentration data for caffeine at reporting levels approximately 10 times lower than those of the wastewater method. Data for these 18 samples are shown in table 6 and figure 2. Of seven samples in which caffeine was not detected by the wastewater method, five also indicated no detection by the pesticide method; however, in the remaining two samples, caffeine was indeed present at the lower concentration detectable by the pesticide method. In addition, for the 10 samples in which caffeine was detected by the wastewater method, it also was detected by the pesticide method. For cases where caffeine was detected by both methods, estimated values obtained by the wastewater method were approximately double those obtained by the pesticide method (table 6, fig. 2). The coefficient of determination $\left(\mathrm{R}^{2}\right)$ for these paired values was 0.78 . Generally, the higher the concentra- 
Table 6. Concentration of caffeine in samples analyzed by the pesticide-analysis method and by the wastewater-analysis method.

[ $\mu \mathrm{g} / \mathrm{L}$, micrograms per liter; MI, Michigan; <, less than; E, estimated]

\begin{tabular}{|c|c|c|c|}
\hline Site & Sampling date & $\begin{array}{l}\text { Concentration of caffeine } \\
\text { by pesticide-analysis } \\
\text { method } \\
(\mu \mathrm{g} / \mathrm{L})\end{array}$ & $\begin{array}{c}\text { Concentration of caffeine } \\
\text { by wastewater-analysis } \\
\text { method } \\
(\mu \mathrm{g} / \mathrm{L})\end{array}$ \\
\hline Pigeon River at Maxwell Road near Rescue, MI & $5 / 17 / 2004$ & $<0.010$ & $<0.5$ \\
\hline Pigeon River at Maxwell Road near Rescue, MI & $8 / 25 / 2004$ & .017 & E.1 \\
\hline Pigeon River near Pigeon, MI & $5 / 17 / 2004$ & .023 & E.1 \\
\hline Pigeon River near Pigeon, MI & $8 / 25 / 2004$ & .022 & $<.5$ \\
\hline Pigeon River near Caseville, MI & $5 / 17 / 2004$ & .028 & E.1 \\
\hline Pigeon River near Caseville, MI & $8 / 25 / 2004$ & .023 & $<.5$ \\
\hline Pinnebog River at Limerick Rd near Pinnebog, MI & $5 / 20 / 2004$ & .017 & E.1 \\
\hline Pinnebog River at Limerick Rd near Pinnebog, MI & $8 / 26 / 2004$ & .031 & E.1 \\
\hline Pinnebog River near Port Crescent, MI & $5 / 20 / 2004$ & .047 & E.11 \\
\hline Pinnebog River near Port Crescent, MI & $8 / 26 / 2004$ & .019 & $<.5$ \\
\hline Pigeon River at Caseville, MI & $5 / 20 / 2004$ & .091 & E. 2 \\
\hline Pigeon River at Caseville, MI & $8 / 26 / 2004$ & .278 & E. 2 \\
\hline Pinnebog River at Moore Road near Elkton, MI & $5 / 17 / 2004$ & .027 & E.1 \\
\hline Pinnebog River at Moore Road near Elkton, MI & $8 / 25 / 2004$ & $<.014$ & $<.5$ \\
\hline Pinnebog River at Richardson Road near Elkton, MI & $5 / 17 / 2004$ & .023 & E.1 \\
\hline Pinnebog River at Richardson Road near Elkton, MI & $8 / 25 / 2004$ & $<.019$ & $<.5$ \\
\hline 16N 11E 13Aadd01 Huron County (Oliver Twp H-14) & $8 / 26 / 2004$ & $<.010$ & $<.5$ \\
\hline 17N 11E 16Dddd Huron County (Chandler Twp H-20) & $8 / 27 / 2004$ & $<.010$ & $<.5$ \\
\hline
\end{tabular}

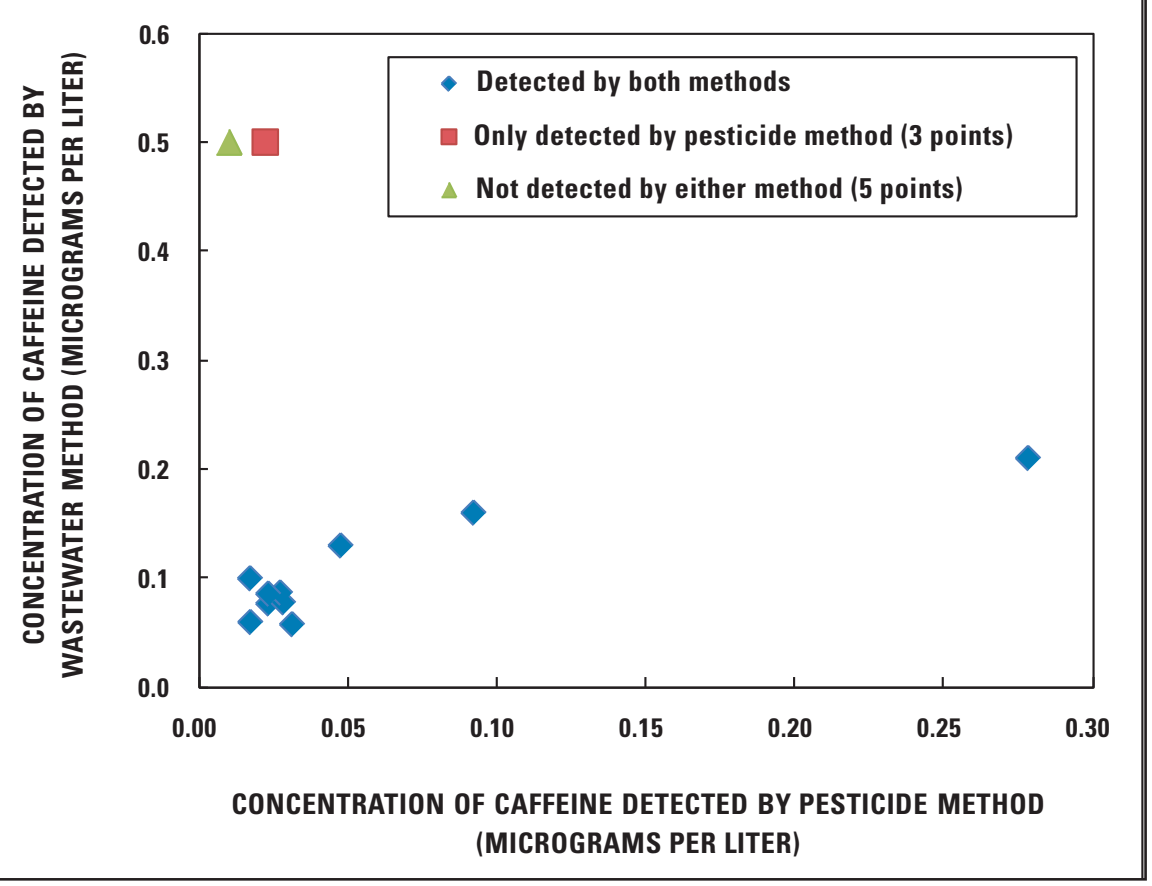

Figure 2. Graph showing relation between concentrations of caffeine determined by two different methods. 
tion determined by both methods, the greater the agreement between the two values. These results indicate two considerations for interpretation of detections and concentrations near the limits of detection for the wastewater method. First, even though a compound is reported as not detected, it may indeed be present. Second, when the compound is reported with an estimated concentration, there is confidence that it is indeed present in the sample, but more uncertainty regarding the actual concentration (as indicated by the E code). Based on these considerations, and assuming other compounds behave as caffeine, compounds detected by the wastewater method in either a primary environmental sample or an associated replicate, but not both, should be considered present in the sample.

In general, field-blank samples indicate that some wastewater compounds, but no pharmaceuticals or antibiotics, may be present owing to contamination of sampling equipment or ambient environmental contamination. Field-blank results provide important information for the design of future sampling programs and may demonstrate the ubiquitous nature of some organic wastewater compounds. Field-replicate results indicate substantial confidence regarding the presence or absence of the many chemicals tested.

\section{Patterns Of Emerging Chemical Detections}

Among the factors known to affect AOPWC occurrence in water at any sampling time are type, proximity, and intensity of source; environmental degradation or dilution of the chemical; and hydrologic variables. Each of these factors may have affected patterns of chemical detections reported herein. Land use may affect the types and concentrations of chemicals detected (Barber and others, 2006). For wastewater-treatmentplant (WWTP) effluents, detections of wastewater chemicals and pharmaceuticals become more frequent and concentrations become greater with increasing size of population served (Kolpin and others, 2004; Spongberg and Witter, 2008). Therefore, the occurrence of a WWTP effluent above a sampling point has a profound effect on the number and concentration of chemicals detected (Kolpin and others, 2004; Glassmeyer and others, 2005; Barber and others, 2006). The effect of WWTP effluents is modified by proximity to the sampling point and by the degree to which river flow dilutes the effluent (Kolpin and others, 2004). Since river flow varies throughout the year, chemical detections also may exhibit seasonal variability. In rural settings, septic systems and agricultural practices (including manure or biosolids application) may affect chemical detections. Detections of antibiotics or pharmaceuticals (both human and veterinary) will be affected by use in the population and by transport pathways, such as rainfall runoff. Therefore, variability in chemical detections and concentrations might be expected. Antibiotics, pharmaceuticals, and wastewater compounds were detected in Michigan at locations and times generally consistent with probable sources and hydrologic conditions.

\section{Antibiotics}

Ten of the 51 antibiotics analyzed were detected at least once. No beta-lactam or tetracycline antibiotics were detected in any sample. The beta-lactam antibiotics degrade rapidly under environmental conditions and are rarely detected in environmental samples (Zuccato and others, 2004). The tetracycline antibiotics exhibit a high affinity for calciumcontaining minerals and bind readily to solids in the environment (Hamscher and others, 2004); therefore, the lack of detection of such compounds is reasonable. In a recent study of untreated surface-water and groundwater drinking-water sources, Focazio and others (2008) reported erythromycin$\mathrm{H}_{2} \mathrm{O}$, trimethoprim, and enrofloxacin to be the most frequently detected antibiotics. Only four additional antibiotics were detected at all: azithromycin, ciprofloxacin, sarafloxacin, and sulfamethoxazole. Similarly, in a study of low-flow samples at selected Iowa streams, the most frequently detected antibiotics were sulfamethoxazole (20 percent), trimethoprim (16.7 percent), and erythromycin- $\mathrm{H}_{2} \mathrm{O}$ (10 percent). Antibioticdetection frequencies for Michigan are similar, as shown in figure 3 .

No antibiotics were detected in two groundwater samples. Antibiotics were detected at 7 of 20 tested surface-water sites. Antibiotics used only for veterinary purposes were detected at two locations: Pinnebog River in Huron County, and Paint Creek near Rochester in Oakland County (fig. 3). These sites are characterized by rural settings, where animals may be prevalent in the watershed. Even the Paint Creek watershed, although located in a generally urban county, has only 11 percent residential and commercial land use and greater than 35 percent agricultural land use above the sampling point. All detections were at very low concentrations and occurred in August, when discharge in Michigan rivers is generally low. Kolpin and others (2004) reported that for selected streams in Iowa, antibiotics and other prescription drugs were frequently detected only during low-flow conditions. Therefore, one possible reason for the lack of detections at other times of the year may be dilution of a small local source by greater river discharge.

General-use antibiotics (fig. 3) were detected at one site in Oakland County (Clinton River at Auburn Hills), but at several sites in Huron County. The Clinton River site is downstream of the discharge point for the Pontiac WWTP, and detections likely reflect this source. The Pinnebog River at Richardson Road receives discharge from a wastewater-treatment lagoon; the lagoon was discharging in April 2004 at the time of sampling. The detections of four antibiotics at the Pinnebog River at Richardson Road, as well as the detection of sulfamethoxazole at downstream locations at Limerick Road and near Port Crescent in April 2004, may reflect this source. 


\section{Veterinary Antibiotics}

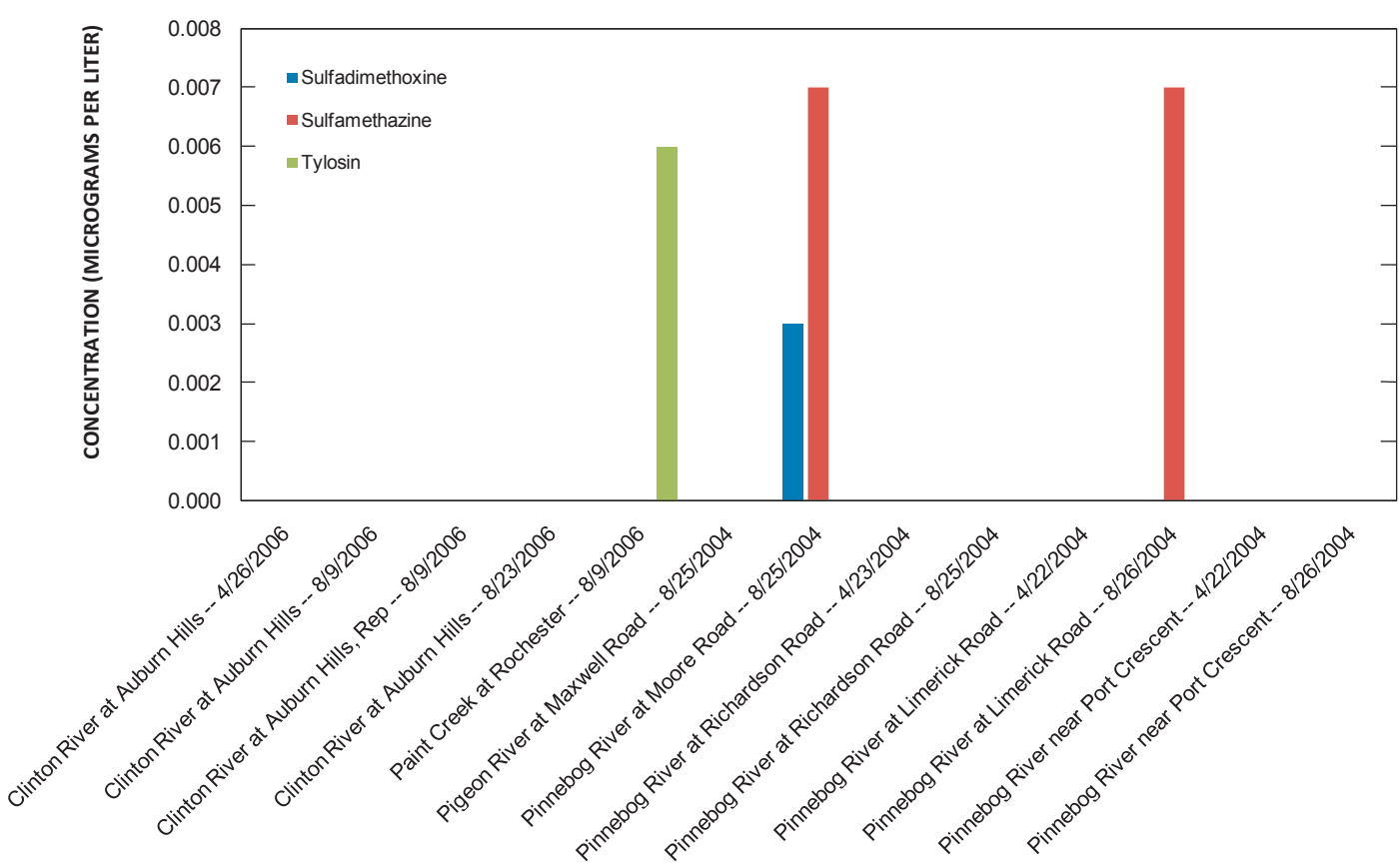

\section{General Use Antibiotics}

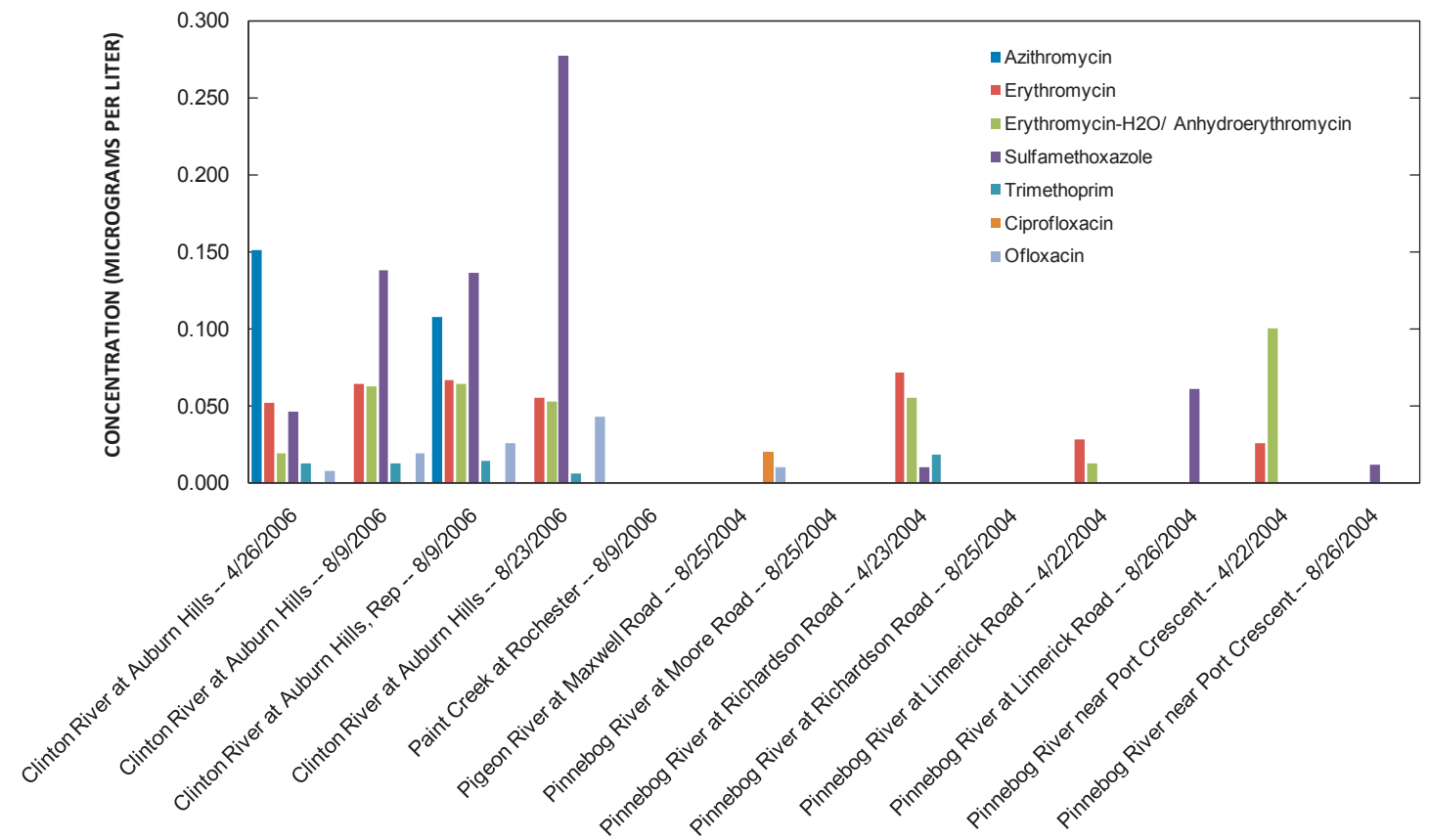

Figure 3. Graphs showing concentrations of veterinary and general use antibiotics at sites where antibiotics were detected. 


\section{Pharmaceuticals}

Five compounds in the pharmaceuticals method (the pharmaceuticals albuterol, dehydronifedipine, thiabendazole, and warfarin, and the antibiotic sulfamethoxazole) were not detected in any sample. Nine of the 14 chemicals analyzed were detected at least once. Of 11 sites sampled for pharmaceuticals (table A2), 4 sites had none detected; however, each of those four sites was sampled only once. In contrast, the Kalamazoo River at New Richmond and the Grand River at Eastmanville were sampled on multiple dates over 3 years. Those two sites accounted for most of the pharmaceutical detections. Diltiazem, diphenhydramine, and trimethoprim were detected at the Grand River site, but never at the Kalamazoo River site. These three chemicals also were detected in the Boardman River at sites within the Traverse City area downstream of the WWTP effluent. Only at the Kalamazoo River site were any chemicals (acetaminophen and caffeine) detected at concentrations substantially above reporting levels.

Patterns of pharmaceutical-compound detections were similar to those reported in other studies. The most frequently detected pharmaceuticals were carbamazepine and caffeine (14 detections in 28 environmental analyses for each of the compounds). Carbamazepine was reported from 100 percent of 11 WWTP effluents at concentrations appreciably above those of background samples (Glassmeyer and others, 2005). That same study indicated carbamazepine was recalcitrant to environmental degradation, which may explain its frequency of detection in Michigan waters. Other pharmaceuticals detected frequently were cotinine (11 detections), acetaminophen ( 9 detections), and trimethoprim (7 detections). All five of these chemicals were among the 35 most commonly detected chemicals in the study by Glassmeyer and others (2005). However, of these latter four chemicals, only trimethoprim occurred in WWTP effluents more frequently than at locations upstream of the effluent outfalls (Glassmeyer and others, 2005). Caffeine may enter surface waters through stormwater runoff or septic systems, and in some geographic settings, plants may produce caffeine naturally (Peeler and others, 2006). Other pharmaceutical compounds may be associated with septic wastes or possibly biosolids applications (Conn and others, 2006; Kinney and others, 2006). In a recent study of untreated surface-water and groundwater drinkingwater sources, Focazio and others (2008) reported cotinine (51 percent of samples), 1,7-dimethyxanthine (27 percent), and carbamazepine (21.6 percent) to be the most frequently detected pharmaceuticals. Similarly, in a study of low-flow samples at selected Iowa streams (Kolpin and others, 2004), the most frequently detected pharmaceuticals were carbamazepine (70 percent), caffeine (56.7 percent), 1,7-dimethylxanthine (53.3 percent), and cotinine (53.3 percent). As Kolpin and others (2004) reported for antibiotics, pharmaceuticals also were most prevalent in low-flow samples in their study.

\section{Wastewater Compounds}

Results of wastewater-compound analyses for 46 unfiltered water samples are summarized by detection frequency in table 7 and similarly for 113 filtered water samples in table 8 . Of 67 chemicals analyzed on unfiltered water, 34 were detected. Of 62 chemicals analyzed on filtered water, 56 were detected. The most frequently detected compound in unfiltered water samples was $N, N$-diethyltoluamide (DEET), a commonly used insect repellant. This chemical also was the second most frequently detected compound in filtered water samples. The most frequently detected compound in filtered water samples was 1,4-dichlorobenzene; DEET and 1,4-dichlorobenzene were detected in field blanks at 31 and 92-percent frequency, respectively, and at concentrations close to those reported in environmental samples (table 5). These two constituents and others detected in field blanks are marked with bold-face lettering in table 8 . There were no field blanks collected for unfiltered water samples, but consideration of field-blank occurrence is recommended when examining table 7 as well as table 8 .

Wastewater compounds detected in Michigan waters are grouped by chemical use or typical source (hereafter referred to as chemical category) in table 9 . Among the chemicals detected in Michigan waters and not detected in field blanks were the musk fragrances hexahydrohexa-methylcyclopentabenzopyran (HHCB) and acetyl hexamethyl tetrahydronaphthlaene (AHTN); triclosan, an antimicrobial ingredient added to many household products; and some detergent metabolites (4-tert-octylphenol and its mono- and di-ethoxylates). AHTN and HHCB, as well as nonyl- and octyl-phenol and their metabolities and several other emerging chemicals often detected in water, have been cited for potential or recognized endocrine-disruption effects (Benotti and others, 2009; Richardson, 2009). AHTN and HHCB have been detected in Great Lakes water and fish (O'Toole and Metcalfe, 2006; Peck and Hornbuckle, 2004; Peck and others, 2006). Triclosan has been cited along with other antimicrobial compounds for the potential to encourage antimicrobial resistance in environmental microorganisms. AHTN, HHCB, and triclosan were persistently detected in WWTP effluents by Glassmeyer and others (2005). Alkylphenols, such as nonylphenol, have been detected in sewage entering the Great Lakes (Barber and others, 2000). In Michigan, HHCB and AHTN were detected in 24 and 25 percent, respectively, of unfiltered water samples and in 27 and 32 percent, respectively, of filtered water samples; triclosan was detected in 7 percent of filtered water samples. Other chemicals detected in more than 10 percent of either filtered or unfiltered water samples, and not detected in field blanks, include pesticides or herbicides (metolachlor and prometon), the flame retardant tri(2-butoxyethyl) phosphate, and several chemicals used in cleaning agents or as fragrances. 
Table 7. Wastewater compounds detected in unfiltered water samples in order of detection frequency.

\begin{tabular}{|c|c|c|c|c|c|c|}
\hline Compound & $\begin{array}{c}\text { Number } \\
\text { of } \\
\text { Analyses }\end{array}$ & $\begin{array}{c}\text { Detected } \\
\text { but not } \\
\text { quantified } \\
\text { (number of } \\
\text { results) }\end{array}$ & $\begin{array}{l}\text { Concentration } \\
\text { estimated } \\
\text { (number of } \\
\text { results) }\end{array}$ & $\begin{array}{l}\text { Concentration } \\
\text { greater than } \\
\text { reporting level } \\
\text { (number of } \\
\text { results) }\end{array}$ & $\begin{array}{c}\text { Not } \\
\text { detected } \\
\text { (number } \\
\text { of results) }\end{array}$ & $\begin{array}{c}\text { Detection } \\
\text { frequency } \\
\text { (percent) }\end{array}$ \\
\hline$N, N$-diethyl-meta-toluamide (DEET) & 17 & 4 & 11 & 0 & 2 & 88 \\
\hline 4-tert-Octylphenol & 17 & 7 & 0 & 0 & 10 & 41 \\
\hline Benzophenone & 17 & 5 & 1 & 0 & 11 & 35 \\
\hline Anthraquinone & 17 & 0 & 5 & 0 & 12 & 29 \\
\hline Tris(2-chloroethyl)phosphate & 45 & 5 & 6 & 0 & 34 & 24 \\
\hline Caffeine & 46 & 8 & 3 & 0 & 35 & 24 \\
\hline 1,4-Dichlorobenzene & 46 & 10 & 1 & 0 & 35 & 24 \\
\hline Tris(2-butoxyethyl)phosphate & 46 & 0 & 10 & 1 & 35 & 24 \\
\hline Acetyl hexamethyl tetrahydronaphthalene (AHTN) & 17 & 3 & 1 & 0 & 13 & 24 \\
\hline Hexahydrohexamethylcyclopentabenzopyran HHCB) & 17 & 0 & 3 & 1 & 13 & 24 \\
\hline Phenanthrene & 46 & 9 & 0 & 0 & 37 & 20 \\
\hline Triethyl citrate (ethyl citrate) & 17 & 2 & 1 & 0 & 14 & 18 \\
\hline Prometon & 17 & 0 & 3 & 0 & 14 & 18 \\
\hline Fluoranthene & 46 & 5 & 3 & 0 & 38 & 17 \\
\hline Tris(dichlorisopropyl)phosphate & 46 & 5 & 2 & 0 & 39 & 15 \\
\hline Cholesterol & 46 & 2 & 5 & 0 & 39 & 15 \\
\hline Pyrene & 46 & 7 & 0 & 0 & 39 & 15 \\
\hline Phenol & 46 & 4 & 2 & 0 & 40 & 13 \\
\hline Tributyl phosphate & 40 & 3 & 2 & 0 & 35 & 13 \\
\hline Tetrachloroethylene & 46 & 3 & 1 & 0 & 42 & 9 \\
\hline Bromoform & 14 & 1 & 0 & 0 & 13 & 7 \\
\hline Bis 2-ethylhexyl phthalate & 29 & 0 & 0 & 2 & 27 & 7 \\
\hline para-Cresol & 46 & 3 & 0 & 0 & 43 & 7 \\
\hline Triphenyl phosphate & 46 & 3 & 0 & 0 & 43 & 7 \\
\hline beta-Sitosterol & 17 & 1 & 0 & 0 & 16 & 6 \\
\hline Camphor & 17 & 0 & 1 & 0 & 16 & 6 \\
\hline Anthracene & 46 & 2 & 0 & 0 & 44 & 4 \\
\hline Bisphenol A & 23 & 1 & 0 & 0 & 22 & 4 \\
\hline d-Limonene & 40 & 1 & 0 & 0 & 39 & 3 \\
\hline 1-Methylnaphthalene & 40 & 1 & 0 & 0 & 39 & 3 \\
\hline 2-Methylnaphthalene & 40 & 1 & 0 & 0 & 39 & 3 \\
\hline Metolachlor & 40 & 1 & 0 & 0 & 39 & 3 \\
\hline Acetophenone & 46 & 1 & 0 & 0 & 45 & 2 \\
\hline Naphthalene & 46 & 1 & 0 & 0 & 45 & 2 \\
\hline 2,6-Dimethylnaphthalene & 23 & 0 & 0 & 0 & 23 & 0 \\
\hline 3-Methyl-1(H)-indole (Skatole) & 17 & 0 & 0 & 0 & 17 & 0 \\
\hline 3-tert-Butyl-4-hydroxy anisole (BHA) & 46 & 0 & 0 & 0 & 46 & 0 \\
\hline 4-Cumylphenol & 17 & 0 & 0 & 0 & 17 & 0 \\
\hline
\end{tabular}


Table 7. Wastewater compounds detected in unfiltered water samples in order of detection frequency. —Continued

\begin{tabular}{|c|c|c|c|c|c|c|}
\hline Compound & $\begin{array}{c}\text { Number } \\
\text { of } \\
\text { Analyses }\end{array}$ & $\begin{array}{l}\text { Detected } \\
\text { but not } \\
\text { quantified } \\
\text { (number of } \\
\text { results) }\end{array}$ & $\begin{array}{l}\text { Concentration } \\
\text { estimated } \\
\text { (number of } \\
\text { results) }\end{array}$ & $\begin{array}{l}\text { Concentration } \\
\text { greater than } \\
\text { reporting level } \\
\text { (number of } \\
\text { results) }\end{array}$ & $\begin{array}{c}\text { Not } \\
\text { detected } \\
\text { (number } \\
\text { of results) }\end{array}$ & $\begin{array}{l}\text { Detection } \\
\text { frequency } \\
\text { (percent) }\end{array}$ \\
\hline 4-n-Octylphenol & 17 & 0 & 0 & 0 & 17 & 0 \\
\hline 4-nonyl phenol & 46 & 0 & 0 & 0 & 46 & 0 \\
\hline 4-Nonylphenol diethoxylate, (sum of all isomers) & 46 & 0 & 0 & 0 & 46 & 0 \\
\hline 4-Nonylphenol monoethoxylate, (sum of all isomers) & 29 & 0 & 0 & 0 & 29 & 0 \\
\hline 4-tert-Octylphenol diethoxylate & 23 & 0 & 0 & 0 & 23 & 0 \\
\hline 4-tert-Octylphenol monoethoxylate & 23 & 0 & 0 & 0 & 23 & 0 \\
\hline 5-Methyl-1H-benzotriazole & 17 & 0 & 0 & 0 & 17 & 0 \\
\hline Atrazine & 23 & 0 & 0 & 0 & 23 & 0 \\
\hline Benzo $[a]$ pyrene & 46 & 0 & 0 & 0 & 46 & 0 \\
\hline beta-Stigmastanol & 17 & 0 & 0 & 0 & 17 & 0 \\
\hline Bromacil & 17 & 0 & 0 & 0 & 17 & 0 \\
\hline Carbaryl & 46 & 0 & 0 & 0 & 46 & 0 \\
\hline Carbazole & 14 & 0 & 0 & 0 & 14 & 0 \\
\hline Chlorpyrifos & 46 & 0 & 0 & 0 & 46 & 0 \\
\hline 3-beta-Coprostanol & 46 & 0 & 0 & 0 & 46 & 0 \\
\hline Cotinine & 17 & 0 & 0 & 0 & 17 & 0 \\
\hline Dichlorvos & 16 & 0 & 0 & 0 & 16 & 0 \\
\hline Diazinon & 46 & 0 & 0 & 0 & 46 & 0 \\
\hline Diethyl phthalate & 6 & 0 & 0 & 0 & 6 & 0 \\
\hline Indole & 17 & 0 & 0 & 0 & 17 & 0 \\
\hline Isoborneol & 17 & 0 & 0 & 0 & 17 & 0 \\
\hline Isophorone & 17 & 0 & 0 & 0 & 17 & 0 \\
\hline Isopropylbenzene & 17 & 0 & 0 & 0 & 17 & 0 \\
\hline Isoquinoline & 17 & 0 & 0 & 0 & 17 & 0 \\
\hline Menthol & 23 & 0 & 0 & 0 & 23 & 0 \\
\hline Metalaxyl & 17 & 0 & 0 & 0 & 17 & 0 \\
\hline Methyl salicylate & 17 & 0 & 0 & 0 & 17 & 0 \\
\hline Pentachlorophenol & 17 & 0 & 0 & 0 & 17 & 0 \\
\hline Triclosan & 23 & 0 & 0 & 0 & 23 & 0 \\
\hline
\end{tabular}


Table 8. Wastewater compounds detected in filtered water samples in order of detection frequency.

[Constituents in bold were detected in field blanks]

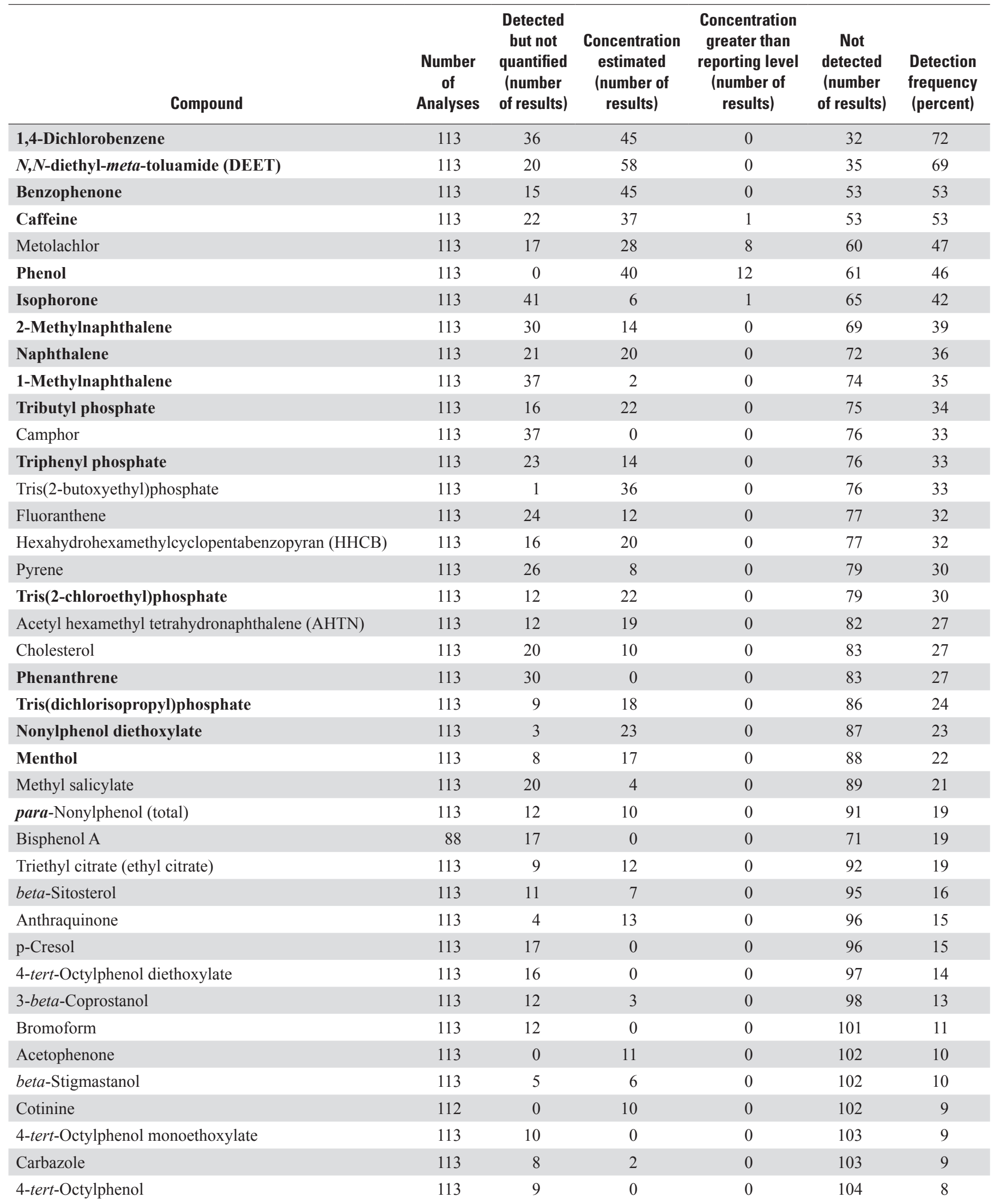


Table 8. Wastewater compounds detected in filtered water samples in order of detection frequency.-Continued

[Constituents in bold were detected in field blanks]

\begin{tabular}{lcccccc}
\hline \multicolumn{1}{c}{ Compound } & $\begin{array}{c}\text { Number } \\
\text { of } \\
\text { Analyses }\end{array}$ & $\begin{array}{c}\text { Detected } \\
\text { but not } \\
\text { quantified } \\
\text { (number } \\
\text { of results) }\end{array}$ & $\begin{array}{c}\text { Concentration } \\
\text { estimated } \\
\text { (number of } \\
\text { results) }\end{array}$ & $\begin{array}{c}\text { Concentration } \\
\text { greater than } \\
\text { reporting level } \\
\text { (number of } \\
\text { results) }\end{array}$ & $\begin{array}{c}\text { Not } \\
\text { detected } \\
\text { (number } \\
\text { of results) }\end{array}$ & $\begin{array}{c}\text { Detection } \\
\text { frequency } \\
\text { (percent) }\end{array}$ \\
\hline Prometon & 113 & 2 & 6 & 0 & 105 & 7 \\
\hline Triclosan & 113 & 8 & 0 & 0 & 105 & 7 \\
\hline Indole & 113 & 6 & 1 & 0 & 106 & 6 \\
\hline Tetrachloroethylene & 113 & 7 & 0 & 0 & 106 & 6 \\
\hline 3-Methyl-1(H)-indole (Skatole) & 113 & 6 & 0 & 0 & 107 & 5 \\
\hline d-Limonene & 113 & 4 & 2 & 0 & 107 & 5 \\
\hline Isopropylbenzene & 113 & 4 & 2 & 0 & 107 & 5 \\
\hline 2,6-Dimethylnaphthalene & 113 & 4 & 0 & 0 & 109 & 4 \\
\hline Anthracene & 113 & 4 & 0 & 0 & 109 & 4 \\
\hline Carbaryl & 113 & 3 & 1 & 0 & 109 & 4 \\
\hline Diazinon & 113 & 1 & 3 & 0 & 109 & 4 \\
\hline Isoborneol & 113 & 4 & 0 & 0 & 109 & 4 \\
\hline Metalaxyl & 113 & 0 & 4 & 0 & 109 & 4 \\
\hline Benzo[a]pyrene & 113 & 2 & 0 & 0 & 111 & 2 \\
\hline Bromacil & 113 & 0 & 1 & 1 & 111 & 2 \\
\hline 5-Methyl-1H-benzotriazole & 113 & 1 & 0 & 0 & 112 & 1 \\
\hline 3-tert-Butyl-4-hydroxy anisole (BHA) & 113 & 0 & 0 & 0 & 113 & 0 \\
\hline 4-Cumylphenol & 113 & 0 & 0 & 0 & 113 & 0 \\
\hline 4-n-Octylphenol & 113 & 0 & 0 & 0 & 113 & 0 \\
\hline Chlorpyrifos & 113 & 0 & 0 & 0 & 113 & 0 \\
\hline Isoquinoline & 113 & 0 & 0 & 0 & 113 & 0 \\
\hline Pentachlorophenol & 85 & 0 & 0 & 0 & 85 & 0 \\
\hline
\end{tabular}

In a recent study of untreated surface-water and groundwater drinking-water sources, Focazio and others (2008) reported cholesterol (59 percent of samples), metolachlor (53 percent of samples), and beta-sitosterol (37 percent of samples) to be the most frequently detected wastewater compounds in surface waters. Similarly, in a study of low-flow samples at selected Iowa streams (Kolpin and others, 2004), the most frequently detected wastewater compounds were metolachlor ( 80 percent), cholesterol (76.7 percent), beta-sitosterol (73.3 percent), and AHTN (36.7 percent). Again, as Kolpin and others (2004) reported for antibiotics and pharmaceuticals, wastewater compounds also were most prevalent in low-flow samples in their study. It is interesting that Michigan waters do not appear to have the frequency of detection of the steroid compounds (cholesterol, beta-sitosterol) as do these other studies. These compounds are naturally occurring and can be derived from many plant and animal sources; however, as with the antibiotic and pharmaceutical data, it is difficult to compare detection frequencies among studies without being able to take into account river flow conditions and proximity to sources at the sampling location. Detections of wastewater compounds for unfiltered water samples are summarized by sampling site and chemical category in table 10 and similarly for filtered water samples in table 11. There were 34 compounds detected at least once in unfiltered water samples (table 7). Of 31 sites for which unfiltered water samples were analyzed, 6 were sampled only once and had no detections. Seven sites were sampled more than once and had no detections of any chemical on at least one date. The maximum number of chemicals detected at any site was 20 (Clinton River at Auburn Hills), followed by 18 detections (Evans Ditch at Southfield), and finally 17 detections (Clinton River at Yates). At these sites and others with large numbers of overall detections, industrial chemicals and human wastewater chemicals (as defined in table 9) accounted 
Table 9. Wastewater compounds detected in filtered water, in Michigan, grouped by chemical use or typical source.

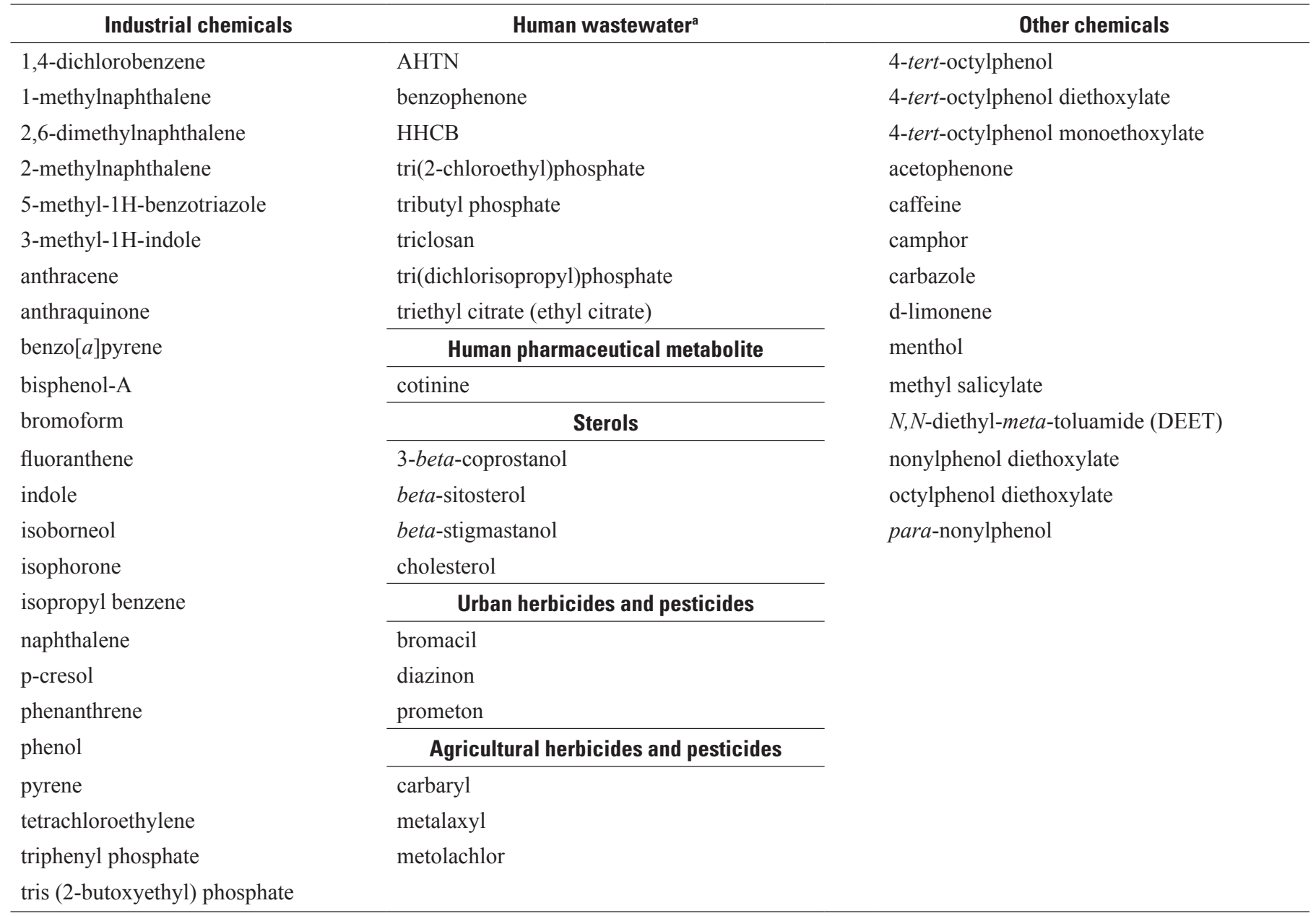

${ }^{a}$ Compounds detected in 100 percent of wastewater-treatment-plant effluents (Glassmeyer and others, 2005).

for the majority of detections. These detections are consistent with the locations of these sites in highly urban settings and in the case of the Clinton River at Auburn Hills, downstream of the City of Pontiac WWTP effluent. Only two herbicides were detected in unfiltered water samples (table 10). Metolachlor, an agricultural-use herbicide, was detected at a location within an agricultural setting. Prometon, an urban-use herbicide, was detected only in urban settings.

There were 56 compounds detected at least once in filtered water samples (table 8 ). There were 40 surface-water sites and 4 groundwater sites for which filtered water samples were analyzed. Two groundwater sites had no detections of any chemical on at least one date. The maximum number of chemicals detected at any groundwater site was 13 (or 11 if the frequently detected blank contaminants 1,4-dichlorobenzene and phenol are not included). The one reported industrialchemical occurrence-Ionia County (Portland Well \#6 on
11/9/2004) — was of phenol. If this detection was discounted as contamination, there would have been no chemicals detected for that well on that date (table 11). No sterols, herbicides or pesticides, or cotinine were detected in groundwater; however, industrial chemicals, human wastewater chemicals, and other chemicals (as defined in table 9) were detected in groundwater (table 11, appendix A4). The two wells in Huron County are monitoring wells not used for water supply, but the Kalamazoo and Ionia County wells are used for supply of drinking water. Although several of the compounds detected in the Kalamazoo and Ionia County wells also were detected in field blanks at least once, at least six chemicals were detected that never occurred in blanks, including AHTN and HHCB (appendix A4). Previous studies have reported differences in the occurrence of wastewater compounds and lower frequency of occurrence of these chemicals in groundwater as compared to surface water (Barnes and others, 2008). 
Table 10. Detections of wastewater compounds in unfiltered water by sampling site, sampling date, and chemical category.

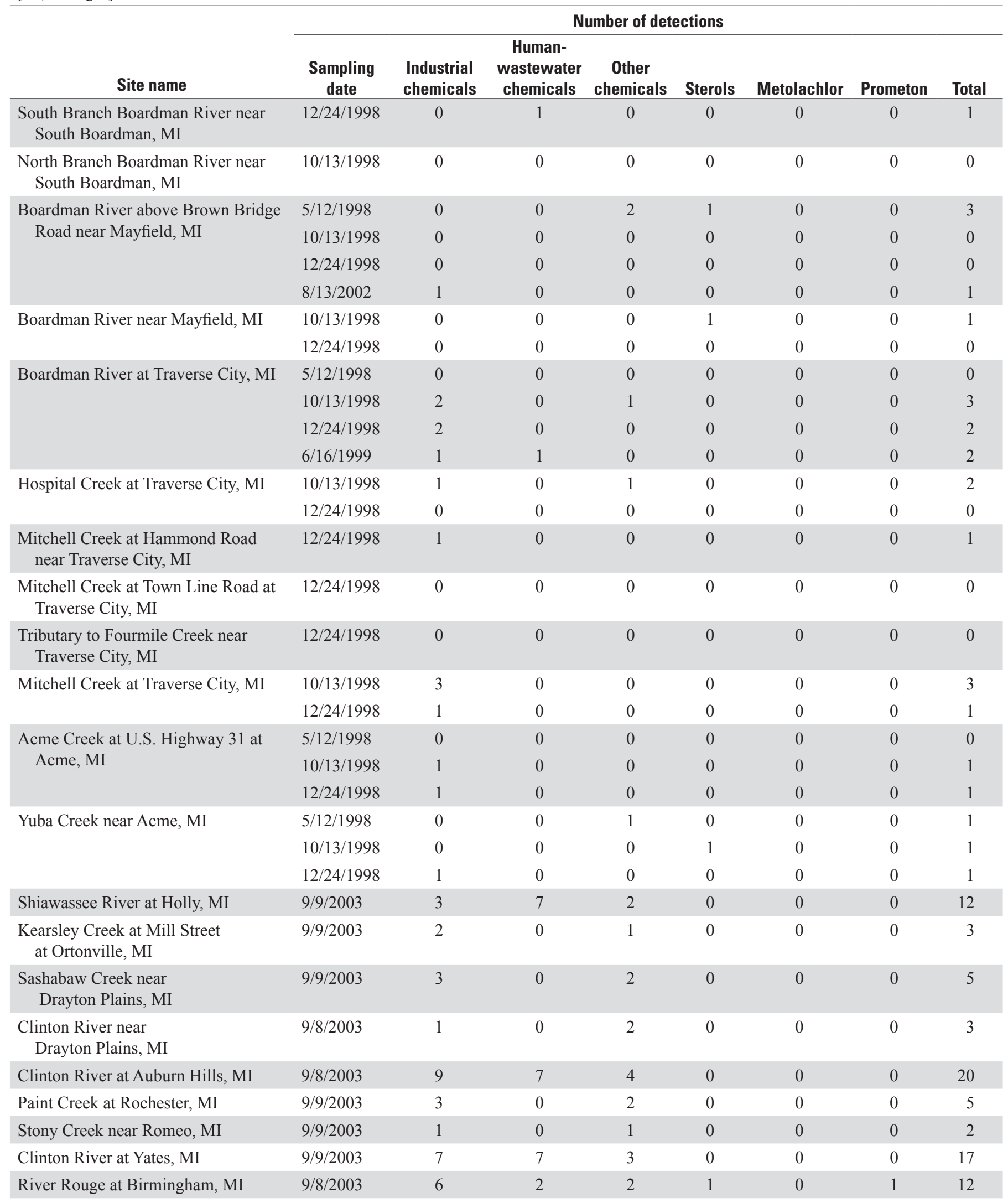


Table 10. Detections of wastewater compounds in unfiltered water by sampling site, sampling date, and chemical category.Continued

\begin{tabular}{|c|c|c|c|c|c|c|c|c|}
\hline \multirow[b]{2}{*}{ Site name } & \multicolumn{8}{|c|}{ Number of detections } \\
\hline & $\begin{array}{c}\text { Sampling } \\
\text { date }\end{array}$ & $\begin{array}{l}\text { Industrial } \\
\text { chemicals }\end{array}$ & $\begin{array}{c}\text { Human- } \\
\text { wastewater } \\
\text { chemicals }\end{array}$ & $\begin{array}{c}\text { Other } \\
\text { chemicals }\end{array}$ & Sterols & Metolachlor & Prometon & Total \\
\hline River Rouge at Southfield, MI & $9 / 8 / 2003$ & 8 & 1 & 2 & 1 & 0 & 1 & 13 \\
\hline Evans Ditch at Southfield, MI & $9 / 8 / 2003$ & 9 & 4 & 3 & 1 & 0 & 1 & 18 \\
\hline $\begin{array}{l}\text { Upper River Rouge at } \\
\text { Clarenceville, MI }\end{array}$ & $9 / 8 / 2003$ & 2 & 2 & 1 & 0 & 0 & 0 & 5 \\
\hline Huron River at Milford, MI & $9 / 8 / 2003$ & 4 & 5 & 4 & 0 & 0 & 0 & 13 \\
\hline Huron River near New Hudson, MI & $9 / 8 / 2003$ & 3 & 1 & 1 & 0 & 0 & 0 & 5 \\
\hline \multirow[t]{2}{*}{ Huron River near Ann Arbor, MI } & 12/19/1999 & 0 & 0 & 0 & 0 & 0 & 0 & 0 \\
\hline & $9 / 10 / 2001$ & 0 & 1 & 1 & 2 & 0 & 0 & 4 \\
\hline $\begin{array}{l}\text { River Raisin near Deerfield, MI } \\
\quad \text { (2nd site) }\end{array}$ & $9 / 11 / 2001$ & 0 & 1 & 0 & 0 & 1 & 0 & 2 \\
\hline $\begin{array}{l}\text { River Raisin near Loyd Road at } \\
\text { Dundee, MI }\end{array}$ & $1 / 1 / 2000$ & 0 & 0 & 0 & 0 & 0 & 0 & 0 \\
\hline
\end{tabular}

Table 11. Detections of wastewater compounds in filtered water by sampling site, sampling date, and chemical category.

[MI, Michigan; data in bold print include either 1,4-dichlorobenzene or phenol; data in bold and italic print include both 1,4-dichlorobenzene and phenol]

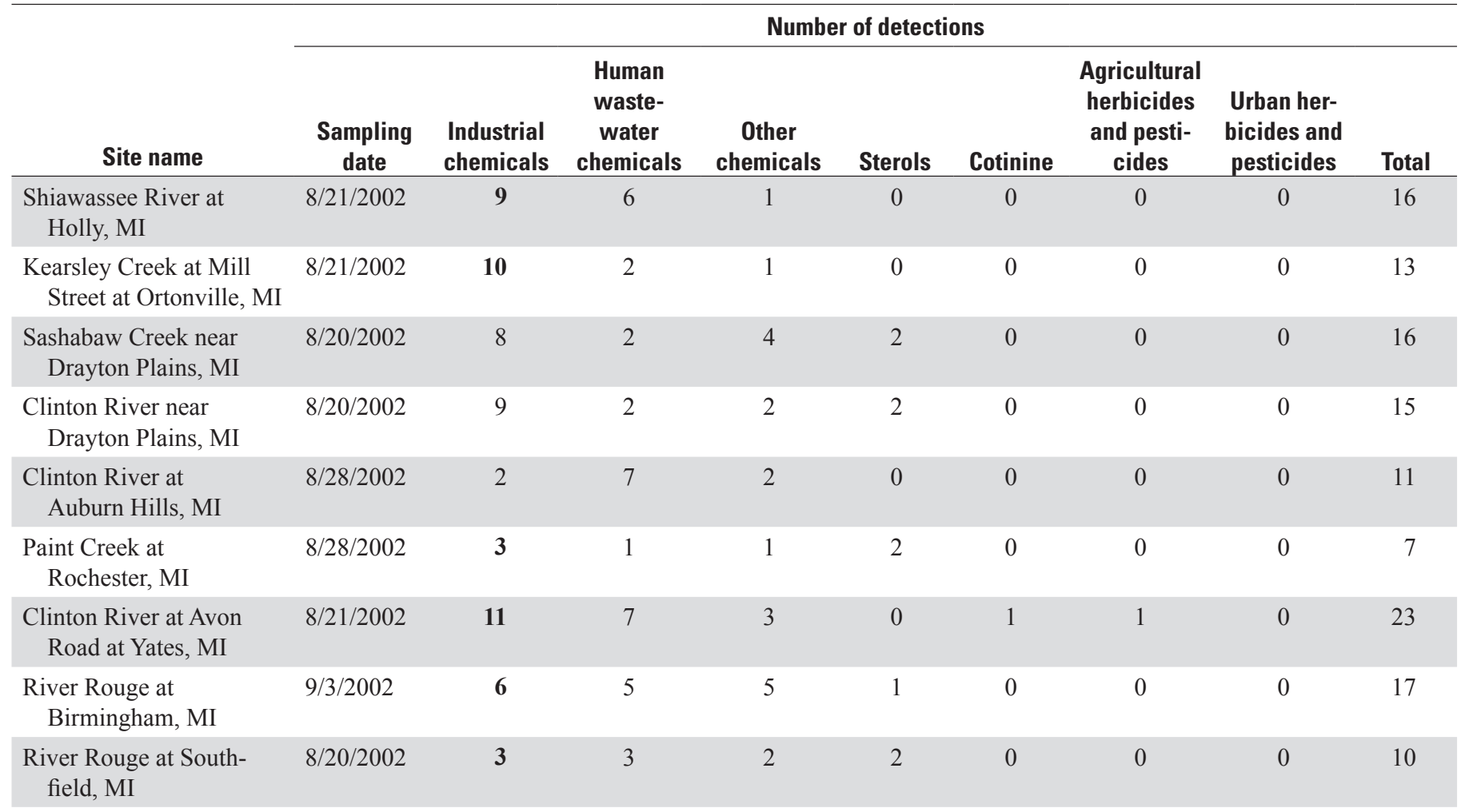


Table 11. Detections of wastewater compounds in filtered water by sampling site, sampling date, and chemical category.-Continued

[MI, Michigan; data in bold print include either 1,4-dichlorobenzene or phenol; data in bold and italic print include both 1,4-dichlorobenzene and phenol]

\begin{tabular}{|c|c|c|c|c|c|c|c|c|c|}
\hline \multirow[b]{2}{*}{ Site name } & \multicolumn{9}{|c|}{ Number of detections } \\
\hline & $\begin{array}{c}\text { Sampling } \\
\text { date }\end{array}$ & $\begin{array}{l}\text { Industrial } \\
\text { chemicals }\end{array}$ & $\begin{array}{c}\text { Human } \\
\text { waste- } \\
\text { water } \\
\text { chemicals }\end{array}$ & $\begin{array}{c}\text { Other } \\
\text { chemicals }\end{array}$ & Sterols & Cotinine & $\begin{array}{l}\text { Agricultural } \\
\text { herbicides } \\
\text { and pesti- } \\
\text { cides }\end{array}$ & $\begin{array}{l}\text { Urban her- } \\
\text { bicides and } \\
\text { pesticides }\end{array}$ & Total \\
\hline $\begin{array}{l}\text { Huron River at } \\
\text { Milford, MI }\end{array}$ & $8 / 20 / 2002$ & 10 & 5 & 5 & 2 & 0 & 0 & 0 & 22 \\
\hline $\begin{array}{l}\text { Huron River near } \\
\text { New Hudson, MI }\end{array}$ & $8 / 28 / 2002$ & 1 & 3 & 1 & 0 & 0 & 0 & 0 & 5 \\
\hline \multirow{2}{*}{$\begin{array}{l}\text { East Branch Galien River } \\
\text { at Gardner Road near } \\
\text { Glendora, MI }\end{array}$} & $8 / 19 / 2003$ & 6 & 1 & 6 & 2 & 0 & 1 & 0 & 16 \\
\hline & $9 / 2 / 2003$ & 4 & 1 & 4 & 1 & 0 & 1 & 0 & 11 \\
\hline \multirow{2}{*}{$\begin{array}{l}\text { Galien River near } \\
\text { Sawyer, MI }\end{array}$} & $8 / 18 / 2003$ & 6 & 1 & 7 & 1 & 0 & 1 & 0 & 16 \\
\hline & $9 / 2 / 2003$ & 5 & 1 & 4 & 3 & 0 & 2 & 0 & 15 \\
\hline $\begin{array}{l}\text { South Branch River } \\
\text { Raisin at Carleton Rd } \\
\text { near Adrian }\end{array}$ & $8 / 13 / 2003$ & 8 & 3 & 6 & 4 & 0 & 1 & 0 & 22 \\
\hline $\begin{array}{l}\text { South Branch River } \\
\quad \text { Raisin near Adrian, MI }\end{array}$ & $8 / 13 / 2003$ & 13 & 7 & 8 & 4 & 1 & 1 & 2 & 36 \\
\hline $\begin{array}{l}\text { Osborn Drain near } \\
\text { Glenwood, MI }\end{array}$ & $10 / 13 / 2004$ & 1 & 0 & 0 & 0 & 0 & 1 & 0 & 2 \\
\hline $\begin{array}{l}\text { Butternut Creek near } \\
\text { South Haven, MI }\end{array}$ & $9 / 8 / 2004$ & 4 & 1 & 3 & 0 & 0 & 1 & 0 & 9 \\
\hline $\begin{array}{l}\text { Little Libhart Creek near } \\
\text { Lyons, MI }\end{array}$ & $9 / 13 / 2004$ & 4 & 0 & 3 & 0 & 0 & 0 & 1 & 8 \\
\hline $\begin{array}{l}\text { Bellamy Creek near } \\
\text { Ionia, MI }\end{array}$ & $9 / 14 / 2004$ & 4 & 0 & 3 & 2 & 0 & 1 & 0 & 10 \\
\hline $\begin{array}{l}\text { Little Thornapple River } \\
\text { near Gresham, MI }\end{array}$ & $10 / 12 / 2004$ & 2 & 0 & 2 & 4 & 0 & 0 & 0 & 8 \\
\hline $\begin{array}{l}\text { Cedar Creek near } \\
\text { Quimby, MI }\end{array}$ & $9 / 23 / 2004$ & 1 & 0 & 1 & 0 & 0 & 0 & 0 & 2 \\
\hline $\begin{array}{l}\text { South Branch White } \\
\text { Creek near Deford, MI }\end{array}$ & $9 / 29 / 2004$ & 3 & 0 & 3 & 2 & 0 & 0 & 0 & 8 \\
\hline $\begin{array}{l}\text { Laird Creek near } \\
\text { Waldron, MI }\end{array}$ & $9 / 15 / 2004$ & 6 & 0 & 6 & 1 & 0 & 1 & 0 & 14 \\
\hline \multirow{2}{*}{$\begin{array}{l}\text { Crystal River Below Dam } \\
\text { near Glen Arbor, MI }\end{array}$} & $5 / 5 / 2004$ & 7 & 4 & 6 & 0 & 0 & 0 & 0 & 17 \\
\hline & $10 / 6 / 2004$ & 1 & 0 & 1 & 4 & 0 & 0 & 0 & 6 \\
\hline $\begin{array}{l}\text { Crystal River near } \\
\text { Glen Arbor, MI }\end{array}$ & $10 / 6 / 2004$ & 1 & 0 & 0 & 4 & 0 & 0 & 0 & 5 \\
\hline \multirow{2}{*}{$\begin{array}{l}\text { Pigeon River at Maxwell } \\
\text { Road near Rescue, MI }\end{array}$} & $5 / 17 / 2004$ & 2 & 1 & 0 & 0 & 0 & 1 & 0 & 4 \\
\hline & $8 / 25 / 2004$ & 2 & 0 & 2 & 0 & 0 & 1 & 0 & 5 \\
\hline \multirow{2}{*}{$\begin{array}{l}\text { Pigeon River near } \\
\text { Pigeon, MI }\end{array}$} & $5 / 17 / 2004$ & 6 & 1 & 3 & 0 & 0 & 1 & 0 & 11 \\
\hline & $8 / 25 / 2004$ & 1 & 0 & 2 & 0 & 0 & 2 & 0 & 5 \\
\hline \multirow{2}{*}{$\begin{array}{l}\text { Pigeon River near } \\
\text { Caseville, MI }\end{array}$} & $5 / 17 / 2004$ & 6 & 0 & 3 & 0 & 0 & 1 & 0 & 10 \\
\hline & $8 / 25 / 2004$ & 3 & 0 & 3 & 0 & 0 & 1 & 0 & 7 \\
\hline
\end{tabular}


Table 11. Detections of wastewater compounds in filtered water by sampling site, sampling date, and chemical category.-Continued

[MI, Michigan; data in bold print include either 1,4-dichlorobenzene or phenol; data in bold and italic print include both 1,4-dichlorobenzene and phenol]

\begin{tabular}{|c|c|c|c|c|c|c|c|c|c|}
\hline \multirow[b]{2}{*}{ Site name } & \multicolumn{9}{|c|}{ Number of detections } \\
\hline & $\begin{array}{l}\text { Sampling } \\
\text { date }\end{array}$ & $\begin{array}{l}\text { Industrial } \\
\text { chemicals }\end{array}$ & $\begin{array}{c}\text { Human } \\
\text { waste- } \\
\text { water } \\
\text { chemicals }\end{array}$ & $\begin{array}{c}\text { Other } \\
\text { chemicals }\end{array}$ & Sterols & Cotinine & $\begin{array}{l}\text { Agricultural } \\
\text { herbicides } \\
\text { and pesti- } \\
\text { cides }\end{array}$ & $\begin{array}{l}\text { Urban her- } \\
\text { bicides and } \\
\text { pesticides }\end{array}$ & Total \\
\hline \multirow{2}{*}{$\begin{array}{l}\text { Pinnebog River at } \\
\text { Limerick Rd near } \\
\text { Pinnebog, MI }\end{array}$} & $5 / 20 / 2004$ & 6 & 1 & 3 & 0 & 0 & 1 & 1 & 12 \\
\hline & $8 / 26 / 2004$ & 2 & 3 & 4 & 0 & 0 & 1 & 1 & 11 \\
\hline \multirow{2}{*}{$\begin{array}{l}\text { Pinnebog River near Port } \\
\text { Crescent, MI }\end{array}$} & $5 / 20 / 2004$ & 6 & 1 & 3 & 0 & 0 & 1 & 1 & 12 \\
\hline & $8 / 26 / 2004$ & 1 & 0 & 2 & 0 & 0 & 1 & 0 & 4 \\
\hline \multirow{2}{*}{$\begin{array}{l}\text { Pigeon River at } \\
\text { Caseville, MI }\end{array}$} & $5 / 20 / 2004$ & 5 & 0 & 3 & 0 & 0 & 1 & 0 & 9 \\
\hline & $8 / 26 / 2004$ & 5 & 0 & 3 & 0 & 0 & 1 & 0 & 9 \\
\hline \multirow{2}{*}{$\begin{array}{l}\text { Pinnebog River at Moore } \\
\text { Road near Elkton, MI }\end{array}$} & $5 / 17 / 2004$ & 2 & 0 & 1 & 0 & 0 & 1 & 0 & 4 \\
\hline & $8 / 25 / 2004$ & 4 & 0 & 2 & 0 & 0 & 1 & 0 & 7 \\
\hline \multirow{2}{*}{$\begin{array}{l}\text { Pinnebog River at } \\
\text { Richardson Road near } \\
\text { Elkton, MI }\end{array}$} & $5 / 17 / 2004$ & 5 & 0 & 1 & 0 & 0 & 1 & 0 & 7 \\
\hline & $8 / 25 / 2004$ & 5 & 0 & 2 & 0 & 0 & 1 & 0 & 8 \\
\hline $\begin{array}{l}\text { 16N 11E 13Aadd01 } \\
\text { Huron County (Oliver } \\
\text { Twp, Well H-14) }\end{array}$ & $8 / 26 / 2004$ & 1 & 1 & 1 & 0 & 0 & 0 & 0 & 3 \\
\hline $\begin{array}{l}\text { 17N 11E 16Dddd } \\
\text { Huron County (Chan- } \\
\text { dler Twp, Well H-20) }\end{array}$ & $8 / 27 / 2004$ & 1 & 1 & 1 & 0 & 0 & 0 & 0 & 3 \\
\hline \multirow{8}{*}{$\begin{array}{l}\text { 01S 11W 34Aa01 } \\
\text { Kalamazoo County } \\
\text { (Parchment Well \#3) }\end{array}$} & $6 / 28 / 2004$ & 1 & 0 & 1 & 0 & 0 & 0 & 0 & 2 \\
\hline & $6 / 29 / 2005$ & 5 & 2 & 2 & 0 & 0 & 0 & 0 & 9 \\
\hline & $8 / 25 / 2005$ & 4 & 0 & 0 & 0 & 0 & 0 & 0 & 4 \\
\hline & $8 / 31 / 2004$ & 0 & 0 & 0 & 0 & 0 & 0 & 0 & 0 \\
\hline & $11 / 9 / 2004$ & 0 & 0 & 0 & 0 & 0 & 0 & 0 & 0 \\
\hline & $3 / 29 / 2005$ & 1 & 1 & 2 & 0 & 0 & 0 & 0 & 4 \\
\hline & $11 / 23 / 2005$ & 7 & 1 & 5 & 0 & 0 & 0 & 0 & 13 \\
\hline & $3 / 22 / 2006$ & 3 & 0 & 0 & 0 & 0 & 0 & 0 & 3 \\
\hline \multirow{8}{*}{$\begin{array}{l}\text { 06N 05W 28Db01 } \\
\text { Ionia County } \\
\text { (Portland Well \#6) }\end{array}$} & $6 / 28 / 2004$ & 2 & 0 & 0 & 0 & 0 & 0 & 0 & 2 \\
\hline & $8 / 31 / 2004$ & 0 & 0 & 0 & 0 & 0 & 0 & 0 & 0 \\
\hline & $11 / 9 / 2004$ & 1 & 0 & 0 & 0 & 0 & 0 & 0 & 1 \\
\hline & $3 / 29 / 2005$ & 1 & 0 & 1 & 0 & 0 & 0 & 0 & 2 \\
\hline & $6 / 16 / 2005$ & 3 & 4 & 4 & 0 & 0 & 0 & 0 & 11 \\
\hline & $8 / 18 / 2005$ & 4 & 1 & 3 & 0 & 0 & 0 & 0 & 8 \\
\hline & $11 / 23 / 2005$ & 7 & 1 & 5 & 0 & 0 & 0 & 0 & 13 \\
\hline & $3 / 23 / 2006$ & 3 & 0 & 0 & 0 & 0 & 0 & 0 & 3 \\
\hline \multirow{8}{*}{$\begin{array}{l}\text { Clinton River at Gratiot } \\
\text { Avenue at Mt. Clem- } \\
\text { ens, MI }\end{array}$} & $6 / 24 / 2004$ & 13 & 6 & 5 & 0 & 0 & 2 & 0 & 26 \\
\hline & $8 / 24 / 2004$ & 4 & 5 & 2 & 0 & 1 & 0 & 0 & 12 \\
\hline & $11 / 3 / 2004$ & 4 & 1 & 4 & 2 & 0 & 0 & 0 & 11 \\
\hline & $3 / 14 / 2005$ & 16 & 7 & 8 & 2 & 1 & 0 & 0 & 34 \\
\hline & $6 / 14 / 2005$ & 19 & 8 & 11 & 4 & 1 & 2 & 1 & 46 \\
\hline & $8 / 15 / 2005$ & 12 & 6 & 10 & 4 & 1 & 2 & 2 & 37 \\
\hline & $11 / 22 / 2005$ & 5 & 2 & 2 & 0 & 0 & 0 & 0 & 9 \\
\hline & $3 / 14 / 2006$ & 15 & 2 & 7 & 0 & 0 & 1 & 0 & 25 \\
\hline
\end{tabular}


Table 11. Detections of wastewater compounds in filtered water by sampling site, sampling date, and chemical category.-Continued

[MI, Michigan; data in bold print include either 1,4-dichlorobenzene or phenol; data in bold and italic print include both 1,4-dichlorobenzene and phenol]

\begin{tabular}{|c|c|c|c|c|c|c|c|c|c|}
\hline \multirow[b]{2}{*}{ Site name } & \multicolumn{9}{|c|}{ Number of detections } \\
\hline & $\begin{array}{l}\text { Sampling } \\
\text { date }\end{array}$ & $\begin{array}{l}\text { Industrial } \\
\text { chemicals }\end{array}$ & $\begin{array}{c}\text { Human } \\
\text { waste- } \\
\text { water } \\
\text { chemicals }\end{array}$ & $\begin{array}{c}\text { Other } \\
\text { chemicals }\end{array}$ & Sterols & Cotinine & $\begin{array}{l}\text { Agricultural } \\
\text { herbicides } \\
\text { and pesti- } \\
\text { cides }\end{array}$ & $\begin{array}{l}\text { Urban her- } \\
\text { bicides and } \\
\text { pesticides }\end{array}$ & Total \\
\hline \multirow{8}{*}{$\begin{array}{l}\text { Grand River near East- } \\
\text { manville, MI }\end{array}$} & $6 / 15 / 2004$ & 9 & 7 & 3 & 0 & 0 & 1 & 1 & 21 \\
\hline & $8 / 18 / 2004$ & 7 & 6 & 5 & 1 & 0 & 1 & 1 & 21 \\
\hline & $11 / 17 / 2004$ & 1 & 1 & 0 & 0 & 0 & 0 & 0 & 2 \\
\hline & $3 / 22 / 2005$ & 10 & 8 & 9 & 1 & 1 & 1 & 0 & 30 \\
\hline & $6 / 27 / 2005$ & 12 & 7 & 4 & 1 & 0 & 1 & 1 & 26 \\
\hline & $8 / 23 / 2005$ & 6 & 6 & 3 & 2 & 1 & 1 & 0 & 19 \\
\hline & $11 / 21 / 2005$ & 9 & 4 & 2 & 0 & 1 & 0 & 0 & 16 \\
\hline & $3 / 13 / 2006$ & 13 & 3 & 3 & 0 & 0 & 1 & 0 & 20 \\
\hline \multirow{8}{*}{$\begin{array}{l}\text { Kalamazoo River at New } \\
\text { Richmond, MI }\end{array}$} & $6 / 15 / 2004$ & 8 & 4 & 2 & 0 & 0 & 1 & 0 & 15 \\
\hline & $8 / 18 / 2004$ & 8 & 3 & 5 & 0 & 0 & 1 & 0 & 17 \\
\hline & $11 / 17 / 2004$ & 1 & 0 & 0 & 0 & 0 & 0 & 0 & 1 \\
\hline & $3 / 21 / 2005$ & 7 & 5 & 5 & 0 & 0 & 1 & 0 & 18 \\
\hline & $6 / 28 / 2005$ & 6 & 4 & 4 & 0 & 0 & 1 & 0 & 15 \\
\hline & $8 / 24 / 2005$ & 7 & 1 & 3 & 0 & 0 & 0 & 0 & 11 \\
\hline & $11 / 22 / 2005$ & 4 & 0 & 0 & 0 & 0 & 0 & 0 & 4 \\
\hline & $3 / 13 / 2006$ & 8 & 3 & 2 & 0 & 0 & 1 & 0 & 14 \\
\hline \multirow{8}{*}{$\begin{array}{l}\text { Muskegon River near } \\
\text { Bridgeton, MI }\end{array}$} & $3 / 13 / 2004$ & 6 & 0 & 2 & 0 & 0 & 1 & 0 & 9 \\
\hline & $6 / 16 / 2004$ & 7 & 2 & 3 & 0 & 0 & 1 & 0 & 13 \\
\hline & $8 / 19 / 2004$ & 0 & 1 & 2 & 0 & 0 & 0 & 0 & 3 \\
\hline & $10 / 27 / 2004$ & 2 & 1 & 3 & 0 & 0 & 0 & 0 & 6 \\
\hline & $3 / 22 / 2005$ & 5 & 3 & 4 & 0 & 0 & 0 & 0 & 12 \\
\hline & $6 / 27 / 2005$ & 7 & 3 & 5 & 0 & 0 & 1 & 0 & 16 \\
\hline & $8 / 23 / 2005$ & 5 & 0 & 1 & 0 & 0 & 0 & 0 & 6 \\
\hline & $11 / 21 / 2005$ & 4 & 0 & 2 & 0 & 0 & 0 & 0 & 6 \\
\hline \multirow{8}{*}{$\begin{array}{l}\text { Saginaw River at } \\
\text { Weadock Road at Es- } \\
\text { sexville, MI }\end{array}$} & $6 / 23 / 2004$ & 13 & 6 & 6 & 0 & 0 & 1 & 0 & 26 \\
\hline & $8 / 24 / 2004$ & 2 & 4 & 2 & 0 & 0 & 1 & 0 & 9 \\
\hline & $11 / 4 / 2004$ & 1 & 0 & 1 & 0 & 0 & 0 & 0 & 2 \\
\hline & $3 / 14 / 2005$ & 11 & 8 & 9 & 3 & 1 & 1 & 0 & 33 \\
\hline & $6 / 15 / 2005$ & 9 & 8 & 6 & 0 & 0 & 1 & 0 & 24 \\
\hline & $8 / 16 / 2005$ & 6 & 6 & 6 & 4 & 0 & 1 & 0 & 23 \\
\hline & $11 / 29 / 2005$ & 9 & 3 & 2 & 0 & 0 & 0 & 0 & 14 \\
\hline & $3 / 14 / 2006$ & 14 & 2 & 3 & 0 & 0 & 1 & 0 & 20 \\
\hline $\begin{array}{l}\text { South Branch } \\
\text { Kalamazoo River near } \\
\text { Moscow, MI }\end{array}$ & $8 / 17 / 2005$ & 6 & 0 & 0 & 0 & 0 & 0 & 0 & 6 \\
\hline
\end{tabular}


Every surface-water site had at least one chemical detected on at least one date. The maximum number of chemicals detected in a single sample at any site was 46 (44 detections if 1,4-dichlorobenzene and phenol are discounted) at the Clinton River at Gratiot Avenue at Mt. Clemens, in June 2005. The second highest site in terms of number of detections in a single sample (37) also was at the Clinton River at Gratiot Avenue at Mt. Clemens, followed by 36 detections at the South Branch of the River Raisin downstream from Adrian. At these sites and others with large numbers of overall detections, industrial chemicals, human wastewater chemicals, and other chemicals (as defined in table 9) accounted for the majority of detections. These detections are again consistent with the locations of these sites downstream of urban areas or known wastewater-effluent discharge points. These patterns are exemplified by the results (table 11, fig. 4) for the two River Raisin sites sampled on August 13, 2003. The Carleton
Road site is located on the river before it passes through the city of Adrian, and the second site is located on the river after it passes through the city. The city of Adrian is one of very few in Michigan that draws its drinking-water supply from a river. Figure 4 shows that the number of detections for most categories of chemicals were greater downstream of Adrian; only sterols and agricultural herbicides and pesticides were similar at both locations. These constituents may reflect the overall agricultural land use in the area. Sterols could arise from runoff of animal wastes, as well as from human wastes. Coprostanol has been reported to be associated with rural land use (Isobe and others, 2004). Kolpin and others (2004) also reported the greatest number of detections of chemicals downstream of urban centers and Barber and others (2006) related increasing detections to increasing population size as they sampled more downstream locations in their study watershed.

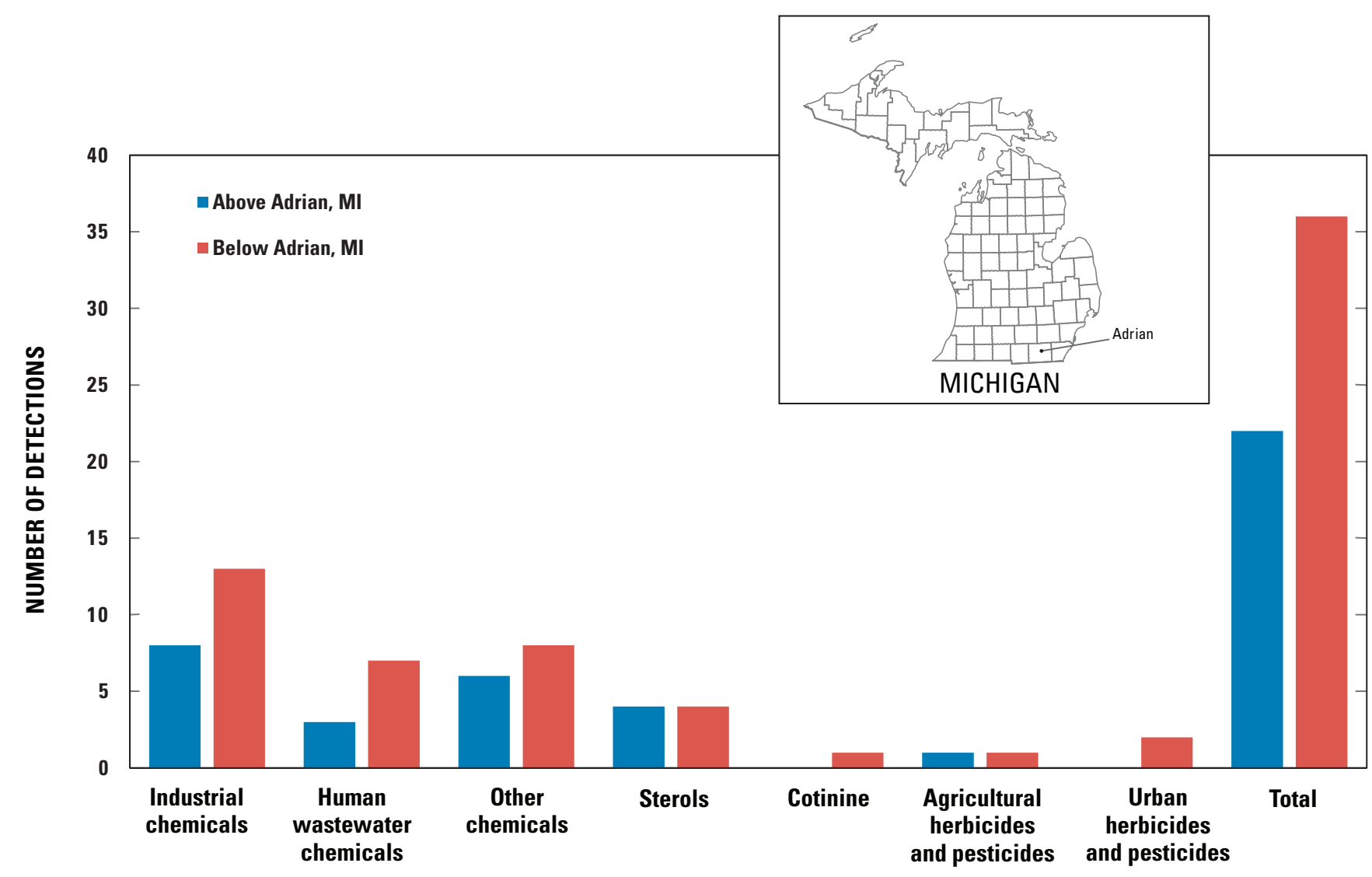

Figure 4. Graph showing number of detections of wastewater compounds, by chemical category, in the River Raisin above and below the city of Adrian, Michigan. 
Five surface-water sites were sampled on multiple dates. For these sites, the number of detections varied with sampling date. In general, for these five sites, the number of detections was lower during October or November than in March or June. No particular chemical category accounted for this pattern. Hydrologic condition is among many factors that may affect the detections of wastewater chemicals in water. The affect of hydrologic condition on wastewater-chemical detections in two branches of the Galien River is shown in figure 5. These rivers were sampled first following a 2-week period of no rainfall, then following the first subsequent rainfall event. In general, higher flow conditions resulted in fewer detections in each chemical category. This is consistent with dilution of wastewater effluent with rainfall runoff. However, as noted previously for the River Raisin, sterols and agricultural herbicide and pesticide detections increased with higher flow at the Galien River site (fig. 5), possibly as a result of surface runoff from agricultural fields. Similar patterns of dilution or concentrations of chemicals in different categories were noted by Kolpin and others, 2004.

\section{East Branch Galien River}

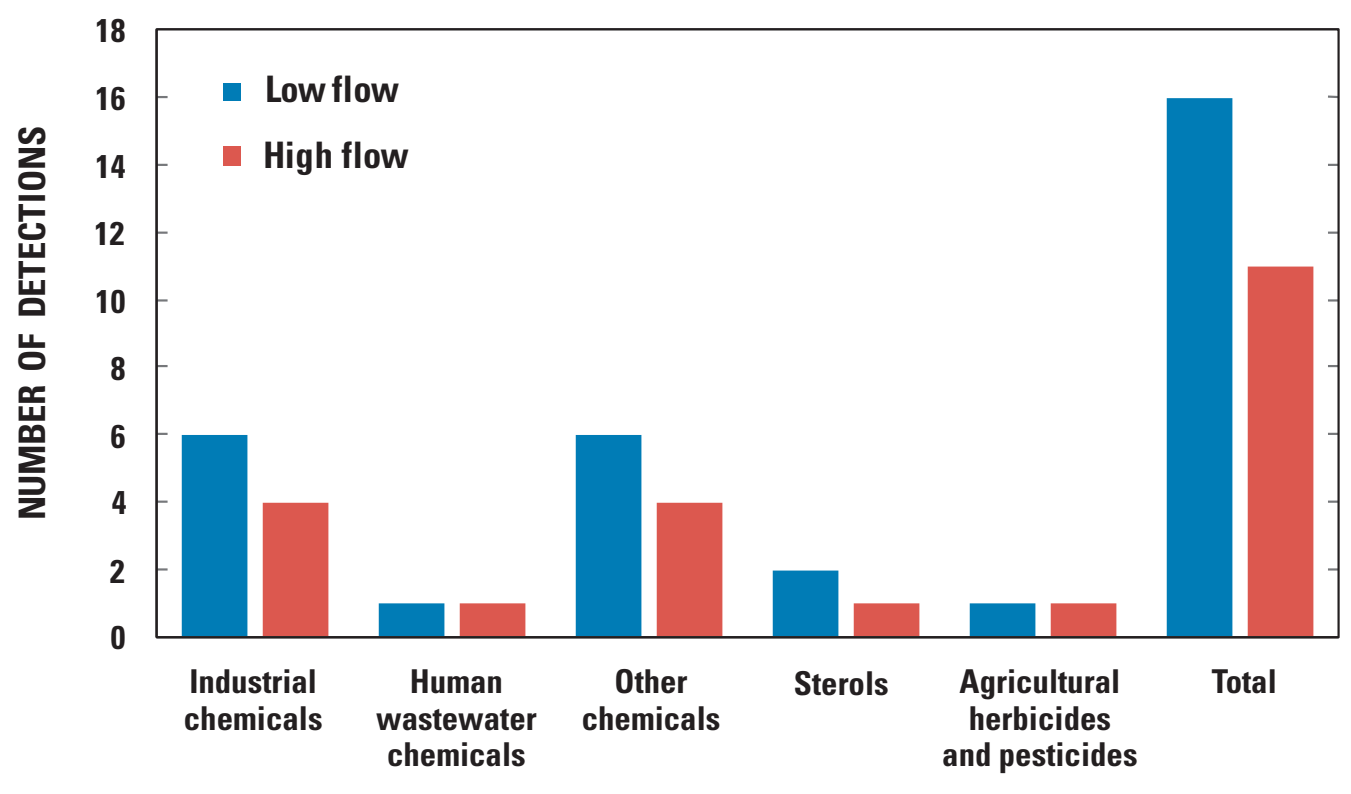

\section{Galien River}

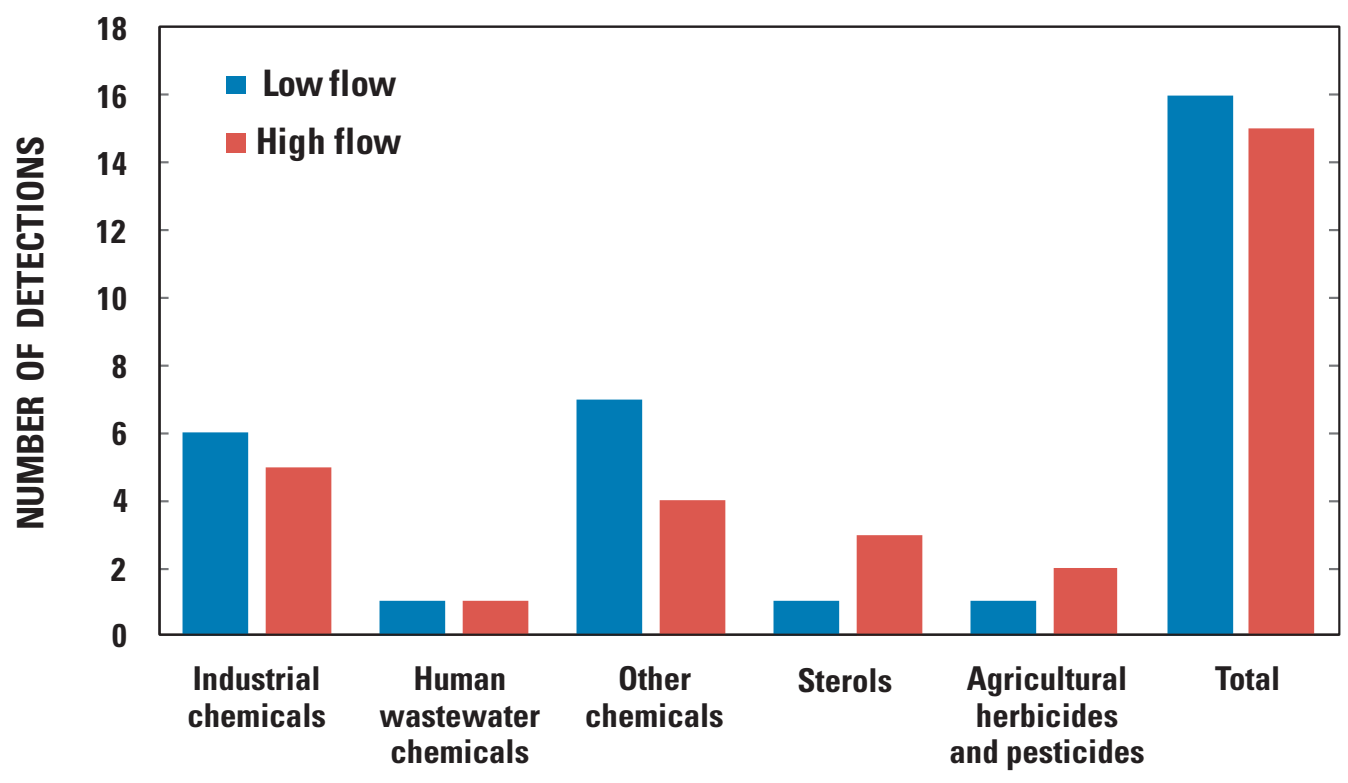

Figure 5. Graphs showing number of detections of wastewater compounds, by chemical category, in two reaches of the Galien River during low- and high-flow conditions. 
Several sites in both Huron and Oakland Counties were analyzed for wastewater chemicals. These counties vary substantially in land use, with Oakland County being highly urban overall and Huron County highly agricultural. Figures 6 and 7 show site-specific detections of wastewater chemicals in four categories as described in table 9: industrial chemicals, human wastewater chemicals, sterols, and other chemicals. Human wastewater chemicals were rarely detected in Huron County, and sterols were never detected (fig. 6). The two Huron County sites with the greatest number of industrial chemicals detected were Pigeon River at Caseville (downstream of the Caseville WWTP) and Pinnebog River at Richardson Road (downstream of intermittent discharge from a sewage lagoon). However, signature human wastewater chemicals (as defined in table 9) were not detected at either of these sites. In contrast, at least one signature human wastewater chemical was detected at each Oakland County site (fig. 7), and industrial chemicals also were generally more prevalent than in Huron
County. Patterns in Oakland County likely reflect proximity to known WWTP discharges, as well as other potential urban inputs such as septic systems or inadvertent connections of sewer lines to storm drains. Several recent reports have argued that various frequently-detected antibiotics, pharmaceuticals, or wastewater chemicals may be useful as indicators of waste effluents and of the potential occurrence of other untested chemicals common to those wastes (Glassmeyer and others, 2005; Benotti and others, 2009).

Figures 6 and 7 demonstrate the potential for multiple APOWCs to be present in various water samples. However, these are not necessarily the only chemicals present. Pesticides and herbicides also were detected (by other analytical methods) in Huron County samples along with the wastewater chemicals reported herein (Duris and Haack, 2005). Pollutants such as industrial chemicals, urban-use pesticides, and nutrients have been commonly detected in the Clinton River (Francis and Haas, 2006).

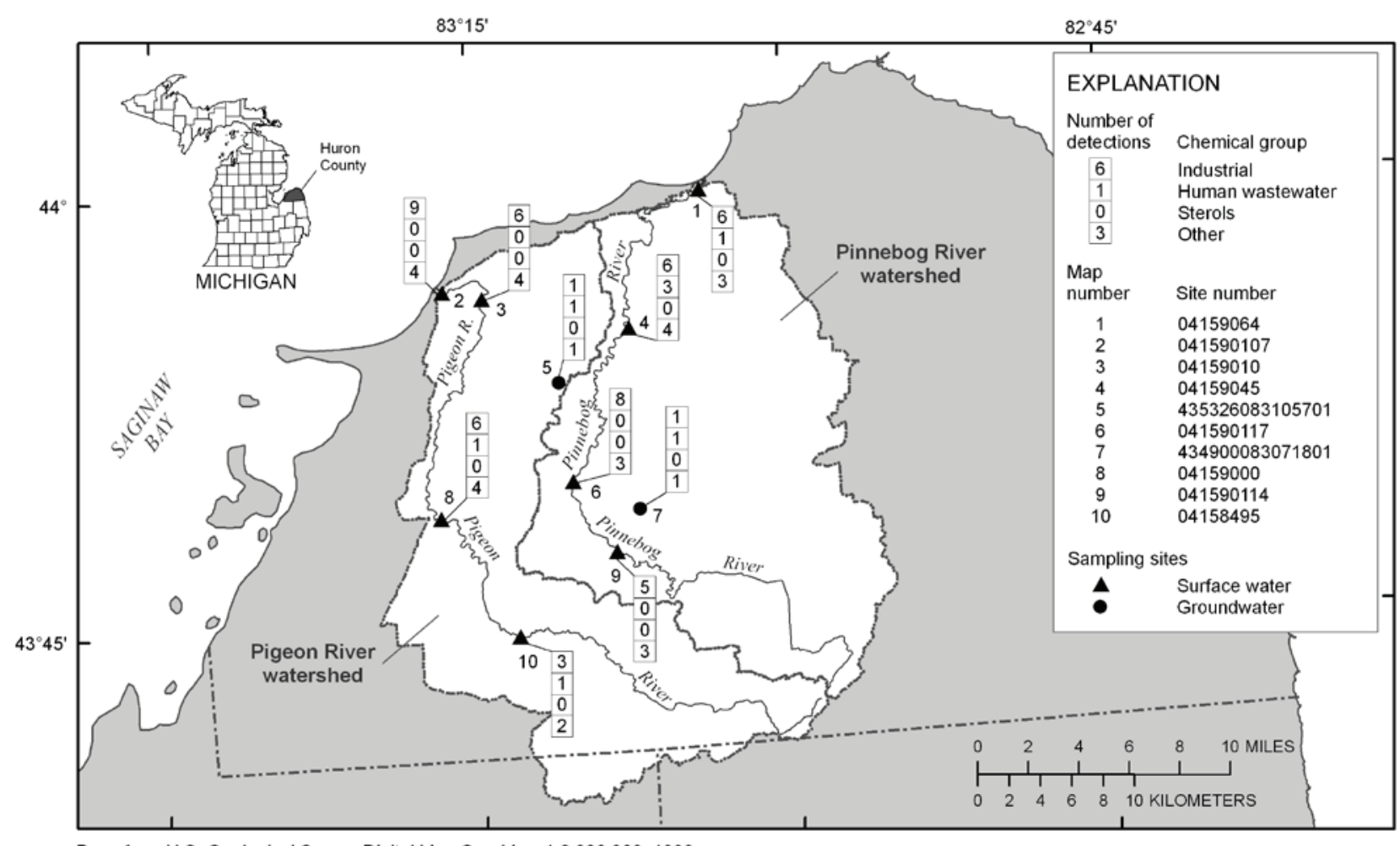

Base from U.S. Geological Survey Digital Line Graphics, 1:2,000,000, 1998

Figure 6. Map of the Pigeon River and Pinnebog River watersheds in Huron County, showing the number of detections of wastewater compounds in four chemical categories, by sampling site. 


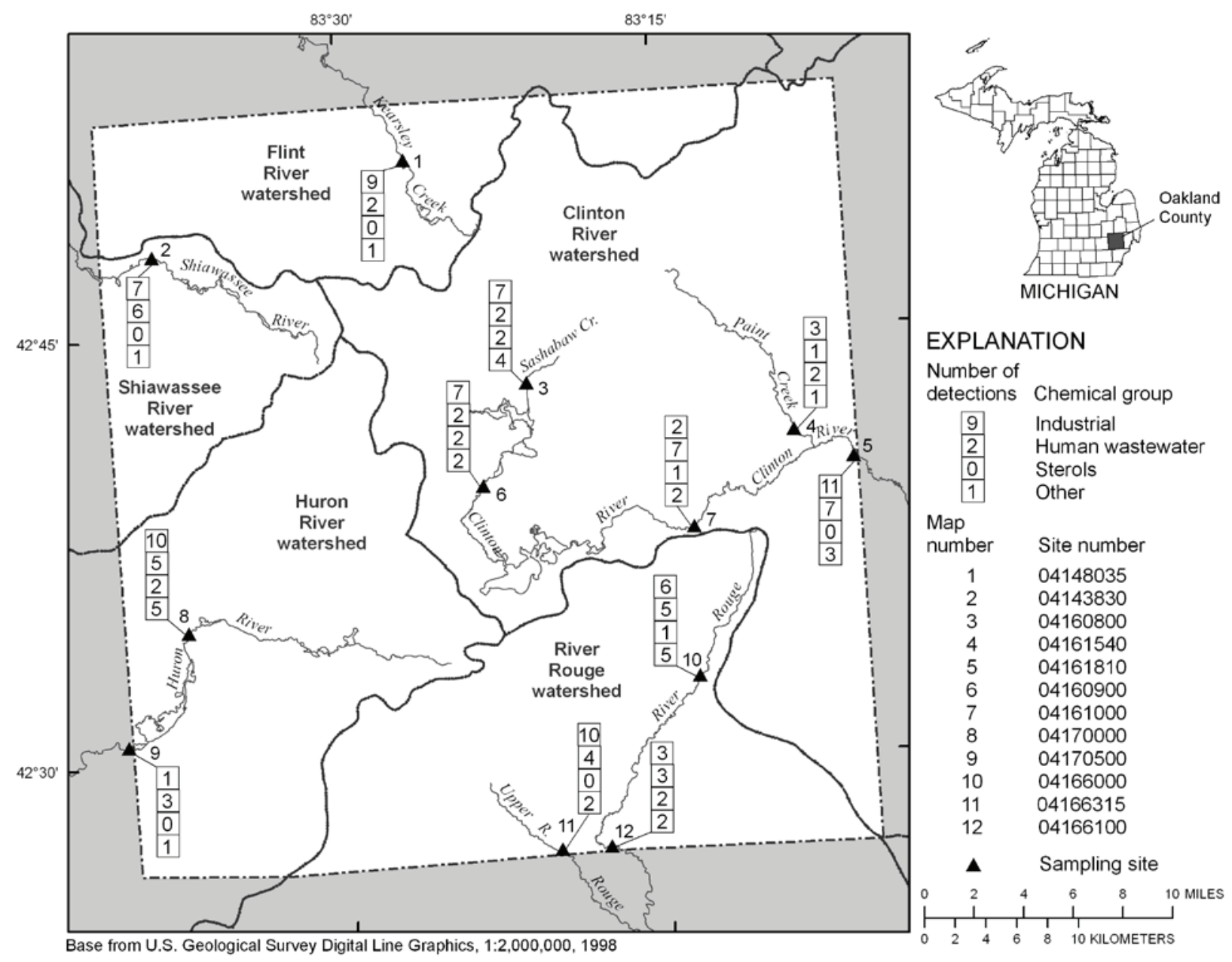

Figure 7. Map of five watersheds in 0akland County, showing the number of detections of wastewater compounds in four chemical categories, by sampling site.

\section{Summary}

Beginning in the late 1990's, the U.S. Geological Survey (USGS) began to develop analytical methods to detect, at concentrations less than 1 microgram per liter $(\mu \mathrm{g} / \mathrm{L})$, emerging water contaminants such as pharmaceuticals, personal-care chemicals, and a variety of other chemicals associated with various human and animal sources. Three separate analytical procedures were used to assess detections and concentrations of the chemicals described in this report. Early data were provided on a provisional basis, with the understanding that method development was an ongoing process and that compounds tested and compound-detection limits might change over time. Reporting levels for many compounds have changed from 1998 to present (2009). In addition, some compounds were removed from, or added to, analysis suites from 1998 to present. In this report, previously reported concentrations less than current reporting levels have been recensored using current reporting criteria to provide consistent information. In addition, data for compounds removed from analytical methods are not included in this report, even though data for such compounds may have appeared in previous USGS or other publications.

During 1998-2005, the USGS analyzed the following Michigan water samples: 41 samples for antibiotic compounds, 28 samples for pharmaceutical compounds, 46 unfiltered samples for wastewater compounds (dissolved and suspended compounds), and 113 filtered samples for wastewater compounds (dissolved constituents only). Very few chemicals were detected at concentrations greater than current (2009) laboratory reporting levels, which currently vary from a low of $0.005 \mu \mathrm{g} / \mathrm{L}$ for some antibiotics to $5 \mu \mathrm{g} / \mathrm{L}$ for some wastewater compounds. Nevertheless, 10 of 51 chemicals in the antibiotics analysis, 9 of 14 chemicals in the pharmaceuti- 
cals analysis, 34 of 67 chemicals in the unfiltered-wastewater analysis, and 56 of 62 chemicals in the filtered-wastewater analysis were detected. Analysis of caffeine by two different methods, one providing concentration data at reporting levels approximately 10 times lower than those of the wastewater method, helps with interpretation of estimated concentrations. Caffeine results showed an overall agreement between the two methods, both in assigning presence or absence of caffeine and in terms of concentrations determined. In general, field-blank samples indicate that some wastewater compounds, but no pharmaceuticals or antibiotics, may be present owing to contamination of sampling equipment or ambient environmental contamination. Field-blank results provide important information for the design of future sampling programs and may demonstrate the ubiquitous nature of some organic wastewater compounds. Field-replicate results indicate substantial confidence regarding the presence or absence of the many chemicals tested.

Antibiotics, pharmaceuticals, and wastewater compounds were detected at the majority of analyzed sites. Antibiotics were detected at 7 of 20 tested surface-water sites, but none were detected in 2 groundwater samples. Pharmaceuticals were detected at 7 of 11 surface-water sites. Wastewater compounds were detected at 25 of 31 sites for which unfiltered water samples were analyzed and at least once at all 40 surface-water sites and all 4 groundwater sites for which filtered water samples were analyzed. Surface-water sites with the largest numbers of detections of chemicals for each analysis method tended to be in urban areas. For example, 46 of 62 wastewater chemicals analyzed for filtered water samples were detected at the Clinton River at Gratiot Avenue at Mt. Clemens in June 2005. In contrast, the maximum number of detected wastewater chemicals in groundwater was 13 . Overall, the chemicals detected most frequently in Michigan waters are similar to those reported frequently in other studies nationwide.

Patterns of chemical detections were site specific, and appeared to be related to local sources, overall land use, and hydrologic conditions at the time of sampling. Sites located on the River Raisin before and after it passes through the city of Adrian were sampled on August 13, 2003. The numbers of detections for most categories of chemicals were greater at the downstream site, which is located after the wastewater-treatment-plant (WWTP) effluent enters the river. Several sites in both Huron and Oakland Counties were analyzed for wastewater chemicals. The two Huron County sites with the greatest number of industrial chemicals detected were Pigeon River at Caseville (downstream of the Caseville WWTP) and Pinnebog River at Richardson Road (downstream of intermittent discharge from a sewage lagoon). However, signature human wastewater chemicals were not detected at either of these sites. In contrast, at least one signature human wastewater chemical was detected at each Oakland County site and industrial chemicals also were prevalent. Patterns in Oakland County likely reflect proximity to known WWTP discharges, as well as other potential urban inputs such as septic systems or connections of sewer lines to storm drains. Patterns of detections with regard to location above or below WWTP effluents, or with respect to general land use, were similar in Michigan to those reported in other studies nationwide.

Hydrologic conditions may affect the numbers and types of chemicals detected. Wastewater effluent may be diluted by rainfall runoff or concentrated at times of low river flow. Two branches of the Galien River were sampled first following a 2-week period of no rainfall, then following the first subsequent rainfall event. In general, higher flow conditions resulted in fewer detections in each chemical category. Five surfacewater sites were sampled for wastewater on multiple dates over 3 years. For these sites, the number of detections varied with sampling date. In general, for these five sites, the number of detections was lower during October or November than in March or June. These patterns could be related to hydrologic conditions at the time of sampling, as has been shown in other studies.

Quality-assurance samples indicated that some wastewater compounds, but no pharmaceuticals or antibiotics, may have been owing to contamination of sampling equipment or ambient environmental contamination. Field-blank results provide important information for the design of future sampling programs in Michigan and demonstrate the need for careful field-study design to avoid some of these ubiquitous organic wastewater compounds. Field-replicate results indicated substantial confidence regarding the presence or absence of the many chemicals tested. Analysis of caffeine by two methods with differing detection levels demonstrated confidence that compounds reported with an estimated concentration are indeed present in the sample, but also demonstrated the degree of uncertainty regarding the actual concentration. Overall, data reported herein indicate that a wide array of antibiotic, pharmaceutical, and organic wastewater compounds occur in Michigan waters. Patterns of occurrence, with respect to hydrologic, land use, and source variables generally appear to be similar for Michigan as for other sampled waters across the United States. The data reported herein can serve as a basis for future studies in Michigan.

\section{References Cited}

Barber, L.B., Brown, G.K., and Zaugg, S.D., 2000, Potential endocrine disrupting organic chemicals in treated municipal wastewater and river water, in Keith, L.H., Jones-Lepp, T.L., and Needham, L.L., eds., Analysis of environmental endocrine disruptors, ACS Symposium Series 747, American Chemical Society: Washington D.C., p. 97-123.

Barber, L.B., Murphy, S.F., Verplanck, P.L., Sandstrom, M.W., Taylor, H.E., and Furlong, E.T., 2006, Chemical loading into surface water along a hydrological, biogeochemical, and land use gradient - A holistic approach: Environmental Science and Technology, v. 40, p. 475-486. 
Barnes, K.K., Kolpin, D.W., Furlong, E.T., Zaugg, S.D., Meyer, M.T., and Barber, L.B., 2008, A national reconnaissance of pharmaceuticals and other organic wastewater contaminants in the United States - I) Groundwater: Science of The Total Environment, v. 402, issues 2-3, p. 192-200.

Barnes, K.K., Kolpin, D.W., Meyer, M.T., Thurman, E.M., Furlong, E.T., Zaugg, S.D., and Barber, L.B., 2002, Water-quality data for pharmaceuticals, hormones, and other organic wastewater contaminants in U.S. streams, 1999-2000: U.S. Geological Survey Open-File Report 02-94, $7 \mathrm{p}$.

Benotti, M.J., Trenholm, R.A., Vanderford, B.J., Holady, J.C., Stanford, B.D., and Snyder, Shane, 2009, Pharmaceuticals and endocrine disrupting compounds in U.S. drinking water: Environmental Science and Technology, v. 43, p. 597-603.

Bonn, B.A., 2008, Using the U.S. Geological Survey National Water Quality Laboratory LT-MDL to evaluate and analyze data: U.S. Geological Survey Open-File Report 2008-1227, $79 \mathrm{p}$.

Boxall, A.B.A., Kolpin, D.W., Halling-Sørensen, B., and Tolls, J., 2003, Are veterinary medicines causing environmental risks?: Environmental Science and Technology, v. 37 , p. $265 \mathrm{~A}-304 \mathrm{~A}$.

Cahill, J.D., Furlong, E.T., Burkhardt, M.R., Kolpin, D.W., and Anderson, L.G., 2004, Determination of pharmaceutical compounds in surface- and ground-water samples by solidphase extraction and high-performance liquid chromatography-electrospray ionization mass spectrometry: Journal of Chromatography A, v. 1041, no. 1-2, p. 171-180.

Conn, K.E., Barber, L.B., Brown, G.K., and Siegrist, R.L., 2006, Occurrence and fate of organic contaminants during onsite wastewater treatment: Environmental Science and Technology, v. 40, p. 7358-7366.

Daughton, C.G., and Ternes, T.A., 1999, Pharmaceuticals and personal care products in the environment-Agents of subtle change?: Environmental Health Perspectives, v. 107 (Supplement 6), p. 907-938.

Delépée, Raphaël, Pouliquen, Hervé, and Le Bris, Hervé, 2004, The bryophyte Fontinalis antipyretica Hedw. bioaccumulated oxytetracycline, flumequine and oxolinic acid in the freshwater environment: Science of The Total Environment, v. 322, issues $1-3$, p. 243-253.

Duris, J.W., and Haack, S.K., 2005, Water-quality data, Huron County, Michigan 2004. U.S. Geological Survey Open-File Report 2005-1380, 30 p.
Focazio, M.J., Kolpin, D.W., Barnes, K.K., Furlong, E.T., Meyer, M.T., Zaugg, S.D., Barber, L.B., and Thurman, M.E., 2008, A national reconnaissance of pharmaceuticals and other organic wastewater contaminants in the United States - II) Untreated drinking water sources: Science of The Total Environment, v. 402, issues 2-3, p. 201-216.

Focazio, M.J., Kolpin, D.W., and Furlong, E.T., 2004, Occurrence of human pharmaceuticals in water resources of the United States-A review, in Kummerer, K., ed., Pharmaceuticals in the environment-Sources, fate, effects, and risks: Berlin, Springer-Verlag, p. 91-106.

Francis, J.T., and Haas, R.C., 2006, Clinton River Assessment: Ann Arbor, Mich., Michigan Department of Natural Resources, Fisheries Division Special Report 39, 78 p., accessed February 27, 2009, at http://www.michigandnr. com/PUBLICATIONS/PDFS/ifr/ifrlibra/special/reports/ sr39/sr39_text.pdf

Furlong, E.T., Werner, S.L., Anderson, B.D., and Cahill, J.D., 2008, Methods of analysis by the U.S.Geological Survey National Water Quality Laboratory, determination of human-health pharmaceuticals in filtered water by chemically modified styrene-divinylbenzene resin-based solid-phase extraction and high-performance liquid chromatography/mass spectrometry: U.S. Geological Survey Techniques and Methods, book 5, chap. B5, 56 p.

Glassmeyer, S.T., Furlong, E.T., Kolpin, D.W., Cahill, J.D., Zaugg, S.D., Werner, S.L., Meyer, M.T., and Kryak, D,D., 2005, Transport of chemical and microbial contaminants from known wastewater discharges - Potential for use as indicators of human fecal contamination: Environmental Science and Technology, v. 39, p. 5157-5169.

Guenther, K., Heinke, V., Thiele, B., Kleist, E., Prast, H., and Raecker, T., 2002, Endocrine disrupting nonylphenols are ubiquitous in food: Environmental Science and Technology, v. 36 , p. $1676-1680$.

Haack, S.K., Duris, J.W., Fogarty, L.R., Kolpin, D.W., Focazio, M.J., Meyer, M., and Furlong, E.W., 2009, Comparison of wastewater chemicals, bacteria concentrations, and bacterial pathogen genes as indicators of fecal pollution: Journal of Environmental Quality, v. 38, p. 1-11.

Halling-Sørensen, B., Nielson, S.N., Lanzky, P.F., Ingerslev, F., Holten Lutzhoft, J., and Jorgensen, S.E., 2002, Occurrence, fate and effects of pharmaceutical substances in the environment -A review: Chemosphere, v. 35, p. 357-393.

Hamscher, G., Pawelzick, H.T., Hüper, H., and Nau, H., 2004, Antibiotics in soil-Routes of entry, environmental concentrations, fate, and possible effects, in Kummerer, K., ed., Pharmaceuticals in the environment-Sources, fate and effects: Berlin, Springer, p. 139-147. 
Hutter, H.P., Wallner, P., Moshammer, H., Hartl, W., Sattelberger, R., Lorbeer, G., and Kundi, M., 2005, Blood concentrations of polycyclic musks in healthy young adults: Chemosphere, v. 59, p. 487-492.

Isobe, K.O., Tarao, M., Chiem, N.H., Minh, L.Y., and Takada H., 2004, Effect of environmental factors on the relationship between concentrations of coprostanol and fecal indicator bacteria in tropical (Mekong Delta) and temperate (Tokyo) freshwaters: Applied and Environmental Microbiology,

v. 70, p. 814-821.

Kinney, C.A., Furlong, E.T., Kolpin, D.W., Burkhardt, M.R., Zaugg, S.D., Werner, S.L., Bossio, J.P., and Benotti, M.J., 2008, Bioaccumulation of pharmaceuticals and other anthropogenic waste indicators in earthworms from agricultural soil amended with biosolid or swine manure: Environmental Science and Technology, v. 40, p. 7105 -7450.

Kinney, C.A., Furlong, E.T., Zaugg, S.D., Burkhardt, M.R., Werner, S.L., Cahill, J.D., and Jorgensen, G.R., 2006, Survey of organic wastewater contaminants in biosolids destined for land application: Environmental Science and Technology, v. 40, no. 23, p. 7207-7215.

Kolpin, D.W., Furlong, E.T., Meyer, M.T., Thurman, E.M., Zaugg, S.D., Barber, L.B., and Buxton, H.T., 2002, Pharmaceuticals, hormones, and other organic wastewater contaminants in U.S. streams, 1999-2000-A national reconnaissance: Environmental Science and Technology, v. 36, no. 6, p. 1202-1211.

Kolpin, D.W., Skopec, M., Meyer, M.T., Furlong, E.T., and Zaugg, S.D., 2004, Urban contribution of pharmaceuticals and other organic wastewater contaminants to streams during differing flow conditions: Science of The Total Environment, v. 328, p. 119-130.

Kurunthachalam, K., Reiner, J.L., Hun Yun, S., Perrotta, E.E., Tao, L., Johnson-Restrepo, B., and Rodan, B.D., 2005, Polycyclic musk compounds in higher tropic level aquatic organisms and human from the United States:

Chemosphere, v. 61, p. 693-700.

Lindqvist, N., Tuhkanen, T., and Kronberg, L., 2005, Occurrence of acidic pharmaceuticals in raw and treated sewages and in receiving waters: Water Research, v. 39, p. 2219-2228.

Meyer, M.T., Lee, E.A., Ferrell, G.F., Bumgarner, J.E., and Varnes, J., 2007, Evaluation of tandem off-line and on-line solid-phase extraction with liquid chromatography/electrospray ionization-mass spectrometry for the analysis of antibiotics in ambient water and comparison to an independent method: U.S. Geological Survey Scientific Investigations Report 2007-5021, 28 p.
Miao, X.S., Yang, J.J., and Metcalfe, C.D., 2005, Carbamazepine and its metabolites in wastewater and biosolids in a municipal wastewater treatment plant: Environmental Science and Technology, v. 39, p. 7469-7475.

O'Toole, S., and Metcalfe, C., 2006, Synthetic musks in fish from urbanized areas of the lower Great Lakes, Canada: Journal of Great Lakes Research, v. 32, p. 361-369.

Paxeus, N., 2004, Removal of selected non-steroidal antiinflammatory drugs (NSAIDs), gemfibrozil, carbamazepine, beta-blockers, trimethoprim and triclosan in conventional wastewater treatment plants in five EU countries and their discharge to the aquatic environment: Water Science and Technology, v. 50, p. 253-260.

Peck A., and Hornbuckle, K.C., 2004, Synthetic musk fragrances in Lake Michigan: Environmental Science and Technology, v. 38, p. 367-372.

Peck A., Linebaugh, E.K., and Hornbuckle, K.C., 2006, Synthetic musk fragrances in Lake Erie and Lake Ontario sediment cores: Environmental Science and Technology, v. 40, p. $5629-5635$.

Peeler, K.A., Opsahl, S.P., and Chanton, J.P., 2006, Tracking anthropogenic inputs using caffeine, indicator bacteria, and nutrients in rural freshwater and urban marine systems: Environmental Science and Technology, v. 40, p. 7616-7622.

Reiner, J.L., Berset, J.D., and Kannan, K., 2007, Mass flow of polycyclic musks in two wastewater treatment plants: Archives of Environmental Contamination and Toxicology, v. 52 , p. $451-457$.

Richardson, S.D., 2009, Water analysis-Emerging contaminants and current issues: Analytical Chemistry, v. 81, p. $4645-4677$.

Spongberg, A. L. and Witter, J.D., 2008, Pharmaceutical compounds in the wastewater process stream in Northwestern Ohio: Science of the Total Environment, v. 397, p. 148-157.

Ternes, T.A., 1998, Occurrence of drugs in German sewage treatment plants and rivers: Water Research, v. 32, p. 3245-3260.

U.S. Environmental Protection Agency, 1997, Guidelines establishing test procedures for the analysis of pollutants (App. B, Part 136, Definition and procedures for the determination of the method detection limit): U.S. Code of Federal Regulations, Title 40, revised as of July 1, 1997, p. 265-267. 
U.S. Environmental Protection Agency, 2005, Guidelines establishing test procedures for the analysis of pollutants (App. B, Part 136, Definition and procedures for the determination of the method detection limit): U.S. Code of Federal Regulations, Title 40, revised as of July 1, 2005, p. 319-322.

U.S. Geological Survey, 2006, Collection of water samples (ver. 2.0): U.S. Geological Survey Techniques of WaterResources Investigations, book 9, chap. A4, accessed April 30, 2009, at http://pubs.water.usgs.gov/twri9A4/.

Wilde, F.D., Radtke, D.B., Gibs, Jacob, and Iwatsubo, R.T., eds., 2004, Processing of water samples (ver. 2.1): U.S. Geological Survey Techniques of Water-Resources Investigations, book 9, chap. A5, accessed April 30, 2009, at http://pubs.water.usgs.gov/twri9A5/

Zaugg, S.D., and Leiker, T.J., 2006, Review of method performance and improvements for determining wastewater compounds (Schedule 1433): U.S. Geological Survey National Water Quality Laboratory Technical Memorandum 2006.01, 16 p., accessed August 3, 2009, at http://nwql.usgs.gov/tech_memos/nwql.2006-01.pdf
Zaugg, S.D., Smith, S.G., and Schroeder, M.P., 2006, Methods of analysis by the U.S. Geological Survey National Water Quality Laboratory_-Determination of wastewater compounds in whole water by continuous liquid-liquid extraction and capillary-column gas chromatography/mass spectrometry: U.S. Geological Survey Techniques and Methods, book 5, chap. B4, 30 p.

Zaugg, S.D., Smith, S.G., Schroeder, M.P., Barber, L.B., and Burkhardt, M.R., 2002, Methods of analysis by the U.S. Geological Survey National Water Quality LaboratoryDetermination of wastewater compounds by polystyrenedivinylbenzene solid-phase extraction and capillary-column gas chromatography/mass spectrometry: U.S. Geological Survey Water-Resources Investigations Report 01-4186, 37 p.

Zuccato, E., Castiglioni, S., Fanelli, R., Bagnati, R., and Calamari, D., 2004, Pharmaceuticals in the environmentChanges in the presence and concentrations of pharmaceuticals for human use in Italy, in Kummerer, K., ed., Pharmaceuticals in the environment-Sources, fate and effects: Berlin, Springer, p. 46-53. 



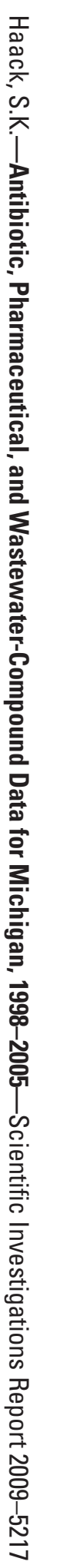

8 Printed on recycled paper 